تغيير بذيرى مؤلفه هاى رسوب با كاربرد ورمى كميوست و نانو كود در سطوح رطوبتى مختلف

ليلا غلامى '"'، عبدالواحد خالدى دروبشان' و نبيه كريمى'

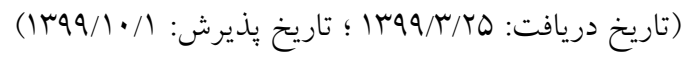

جكيده

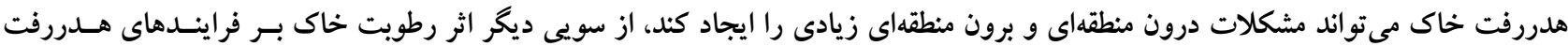

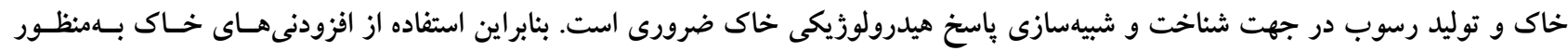

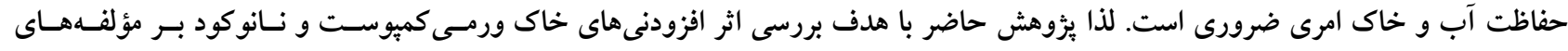

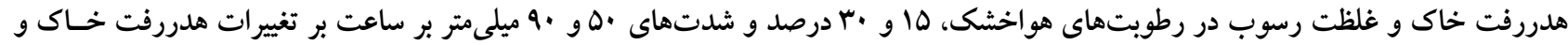

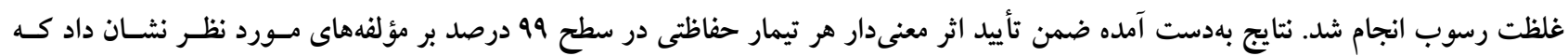

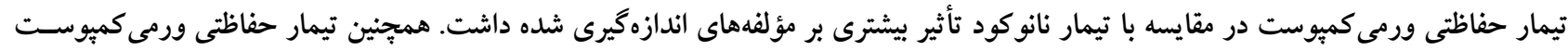

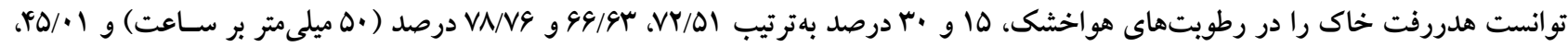

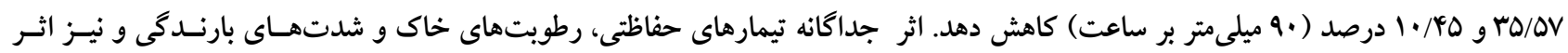

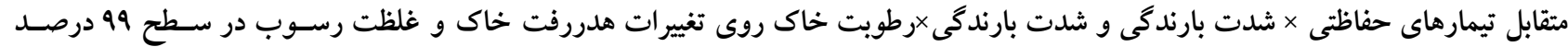

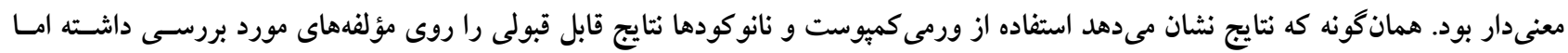

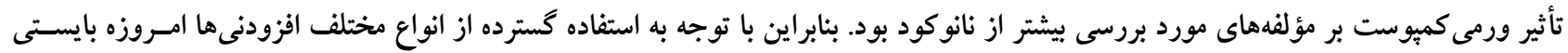

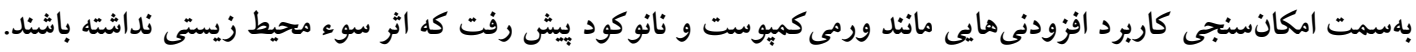

وازههاى كليدى: اصلاح كندهاى خاك، فرسايش خاك، رطوبت ييشين خاك، غلظت رسوب، كرت آزمايشكاهى

1. كُوه مهندسى آبخيزدارى، دانشگاه علوم كشاورزى و منابع طبيعى سارى، سارى، ايران

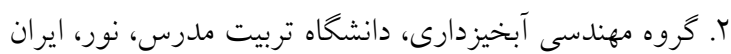

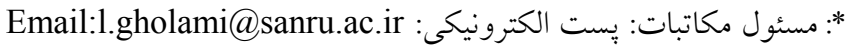




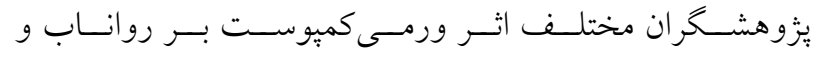

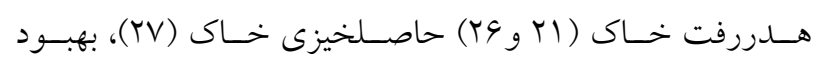

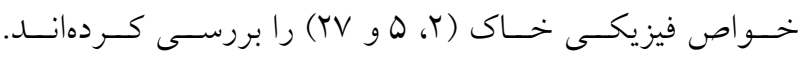

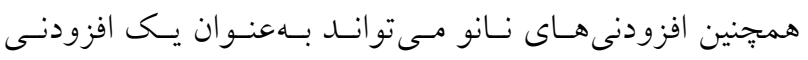

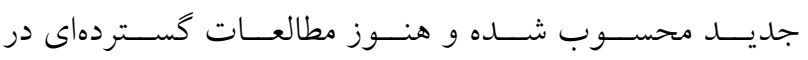

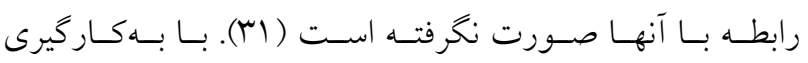

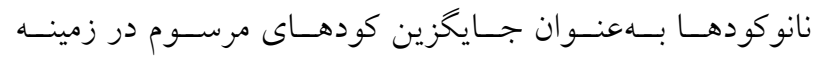

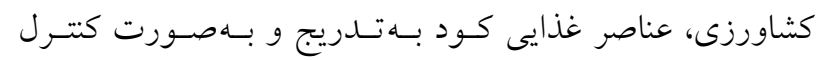

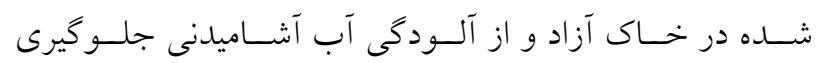

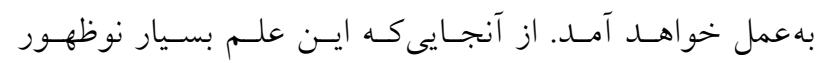

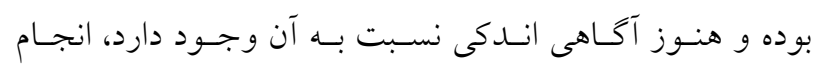

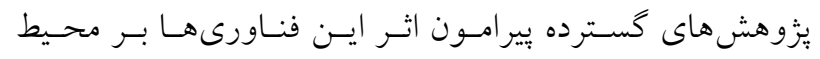

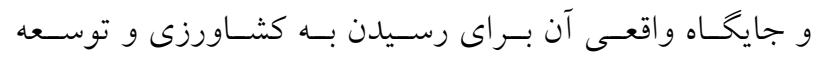

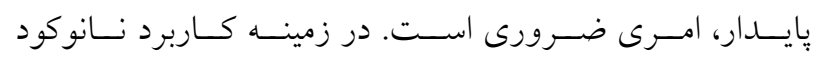

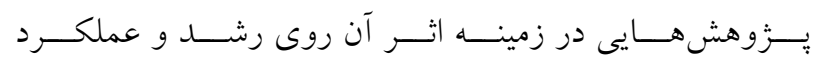

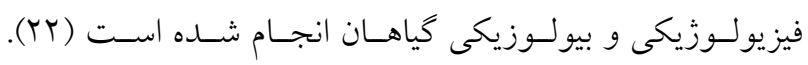

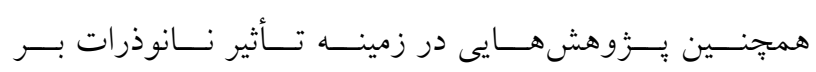

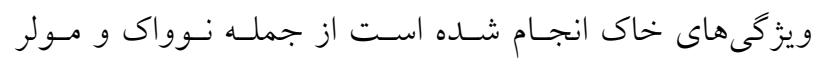

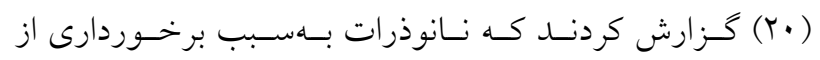
نسبت سطح بـه حجـم و قابليـت جـذب زيــاد، امكـان اتصـال

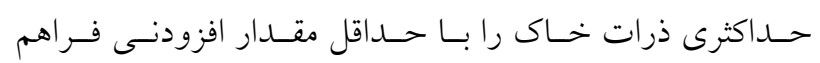

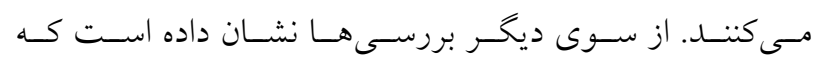

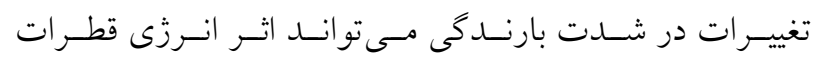

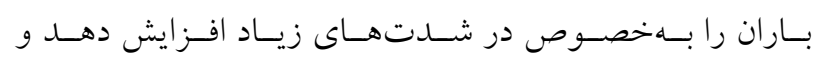

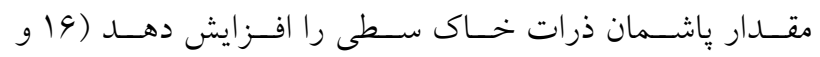

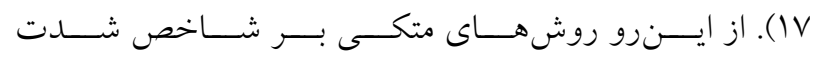

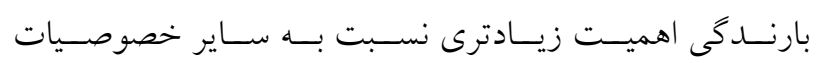

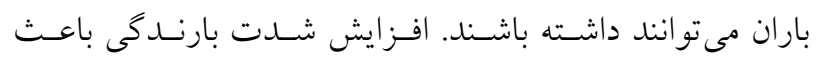

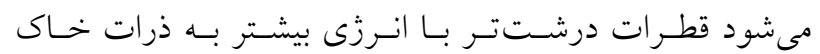

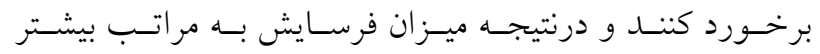

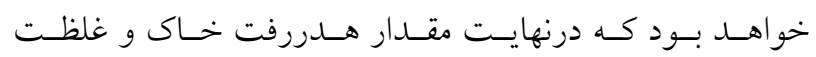

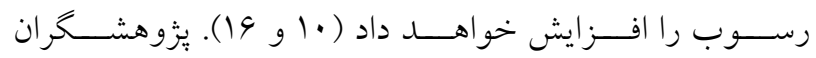

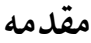

هــررفت خـاك يكسى از معضـلات جهـانى بـوده كـه عـلاوه

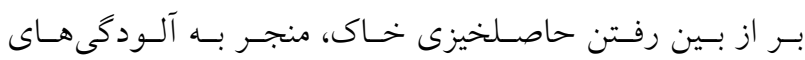

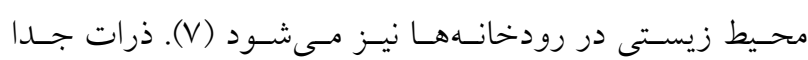

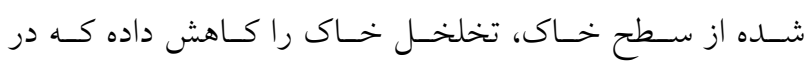

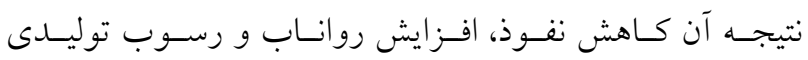

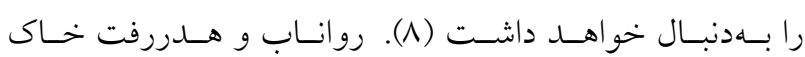

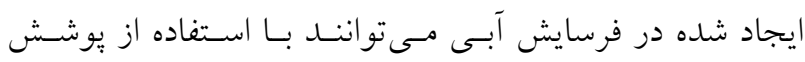

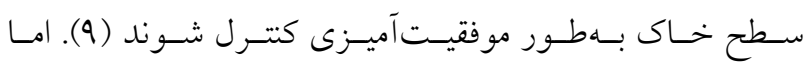

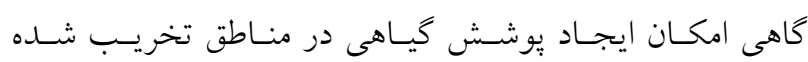

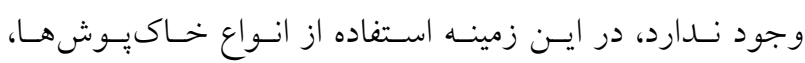

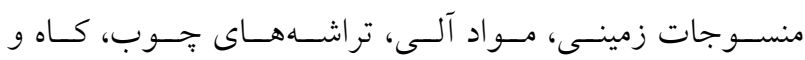

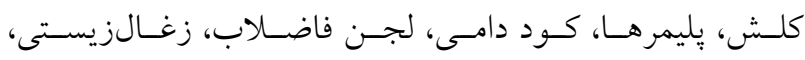

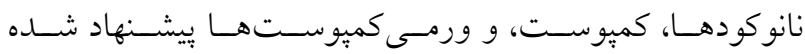

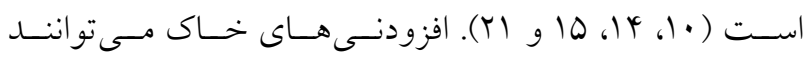

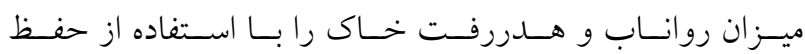

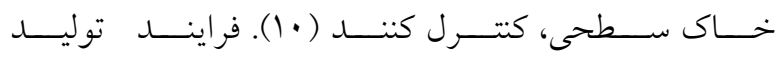

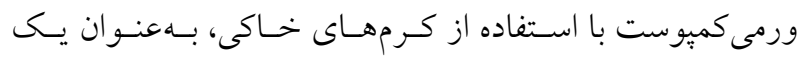

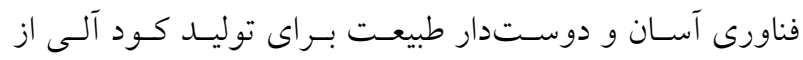

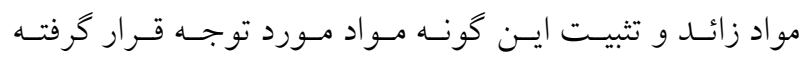

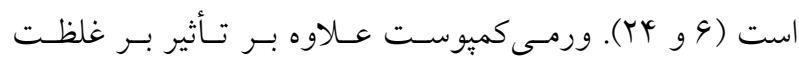

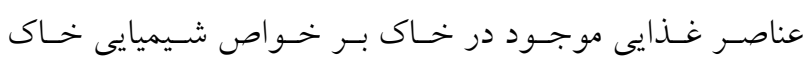

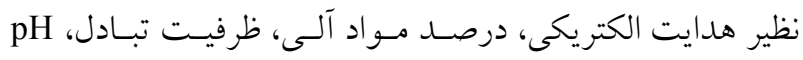

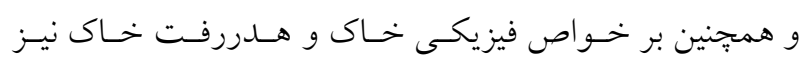

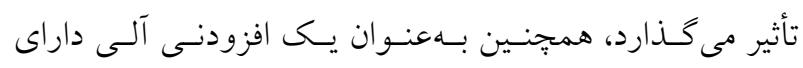

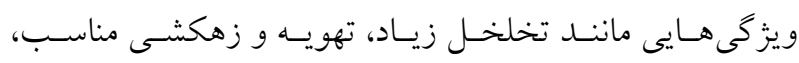

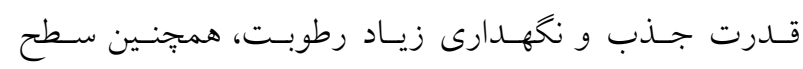

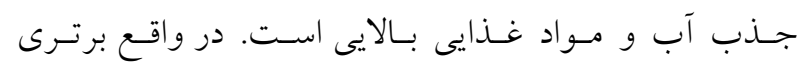

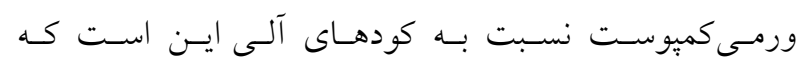
بـهنهـوبى تغييـر سـاختار داده و تعسداد موجــودات ريـز

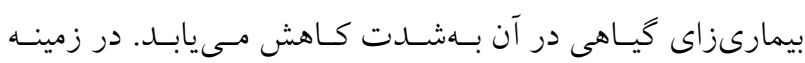

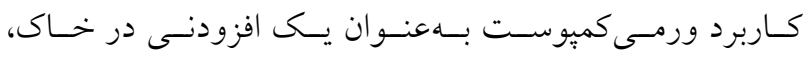


متفــاوت در رطوبــتهــاى مختلــف را ارزيـابى كنـــ، ثبـت

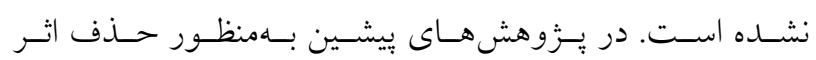

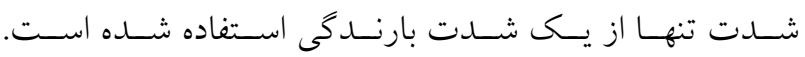

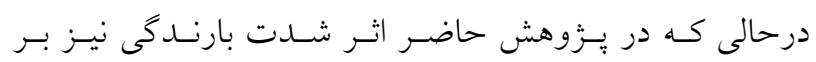

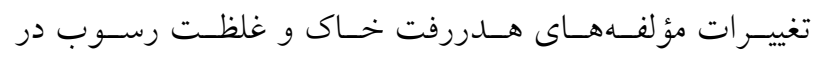

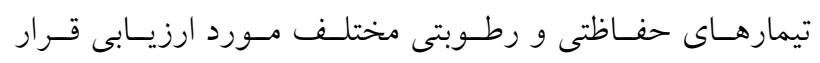

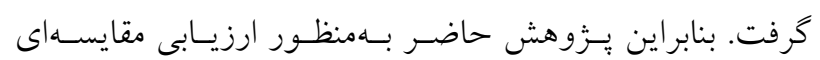

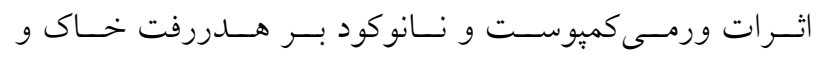

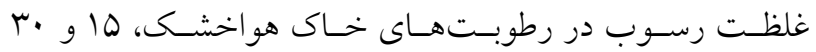

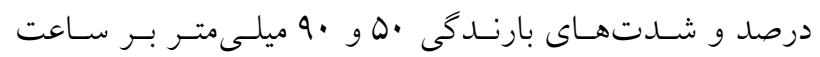

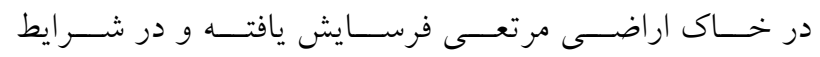

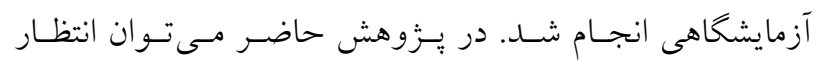
داشت كه اثر ورمسى كميوسـت و نـانوكود بــر تغييـرات مؤلفـهـ-

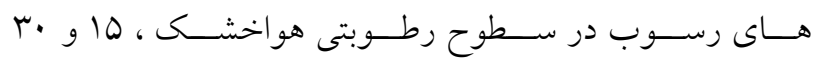

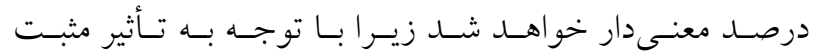

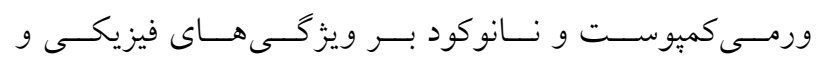

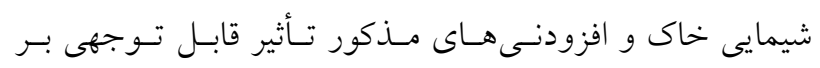

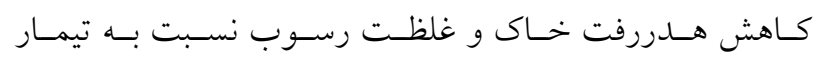

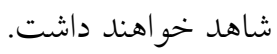

\section{مواد و موش} - تهيه و آمادهسازى خاك وפسك

آزمايشهاى مربوط به بخش جمع آورى رسـوب در آزمايشـاه

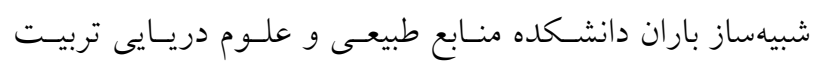

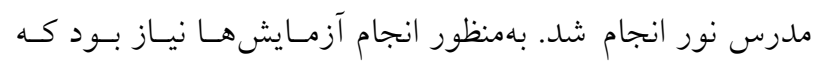

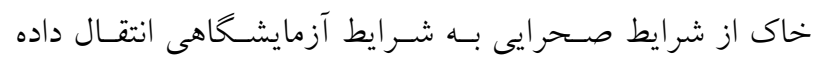

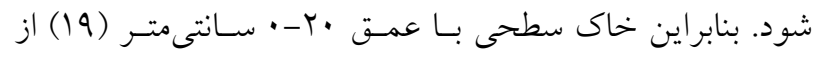

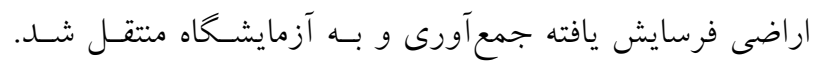

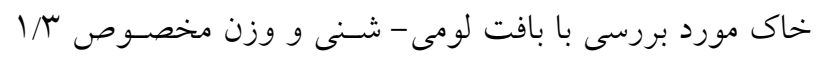

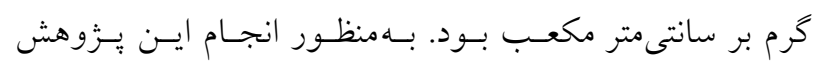

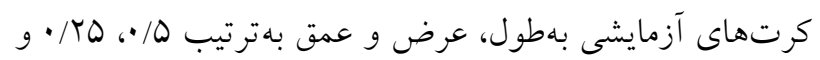

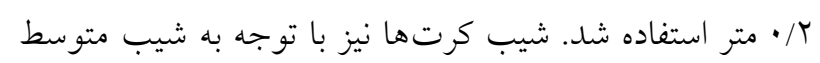

متعـددى نظيـر غلامسى و همكــاران (9) و خالـــى درويشـان

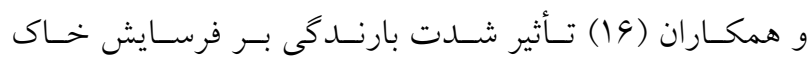

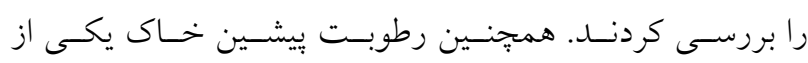

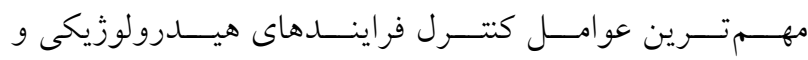

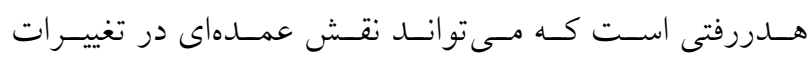

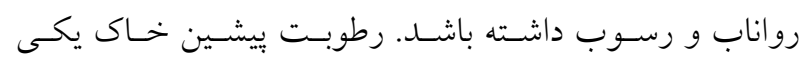

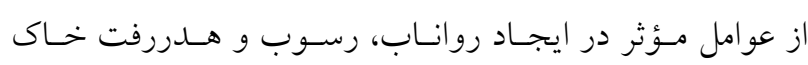

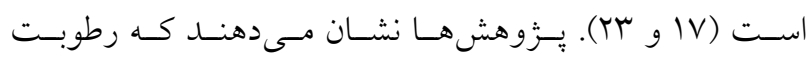

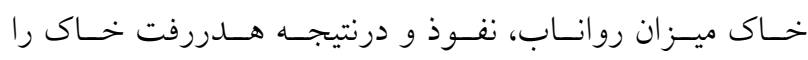

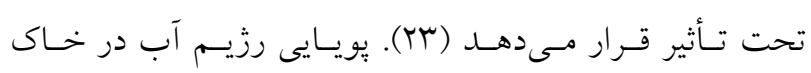

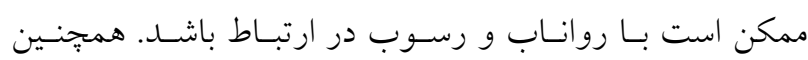

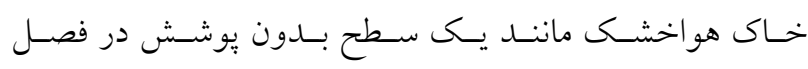

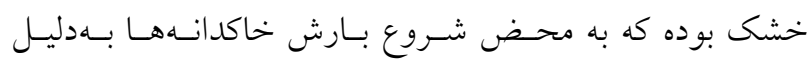

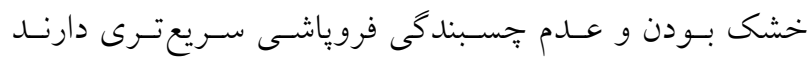

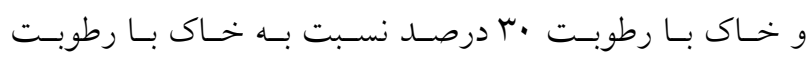

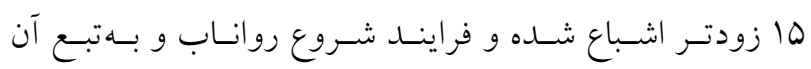

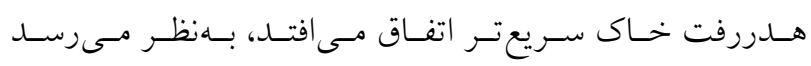

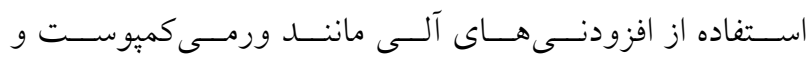

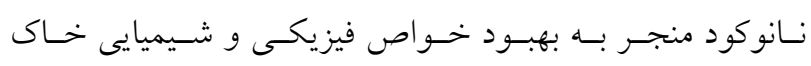

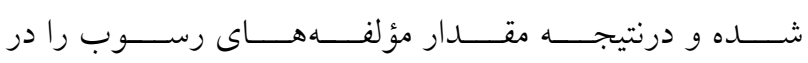

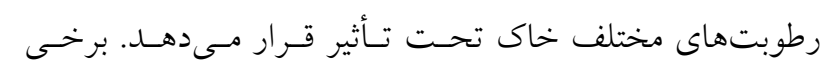

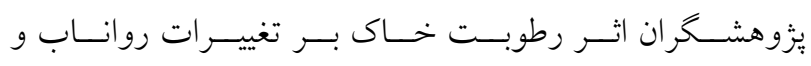

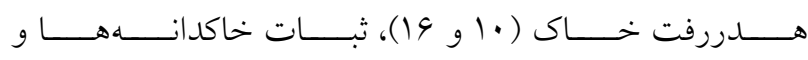

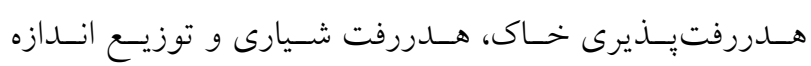

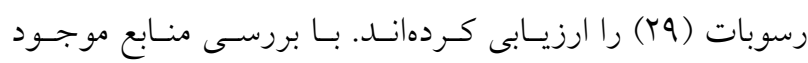

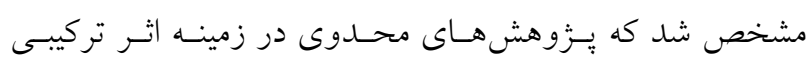

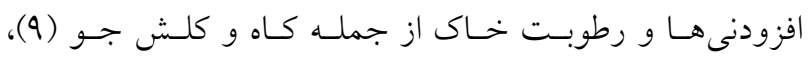

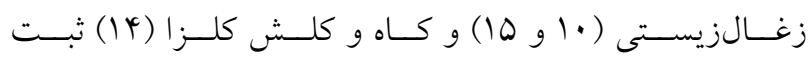

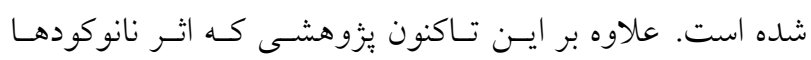

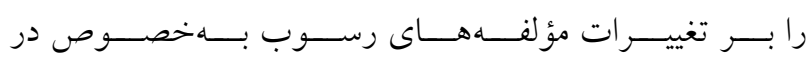

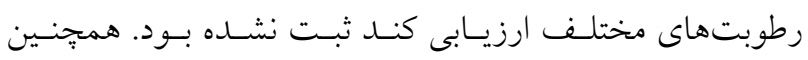

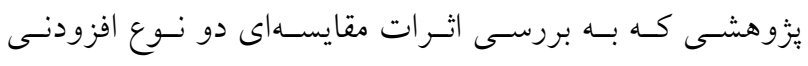


- سامانه شبيهساز باران و انتخاب شدت بارندگى -

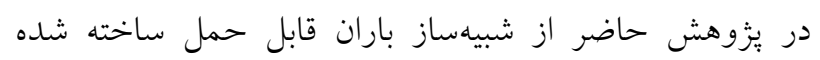

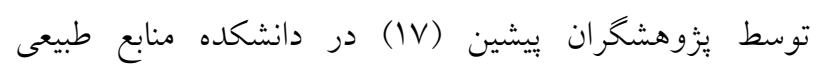

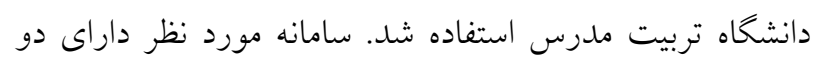

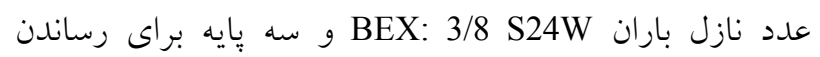

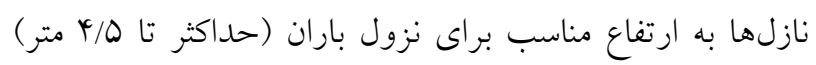

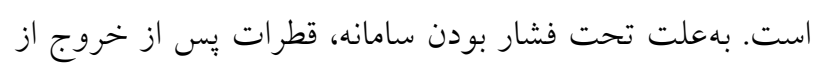

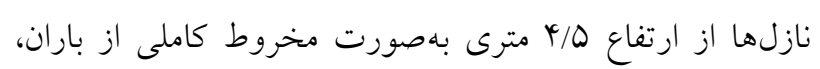

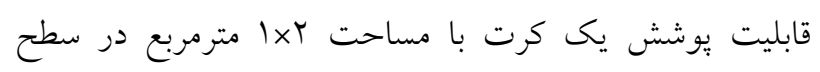

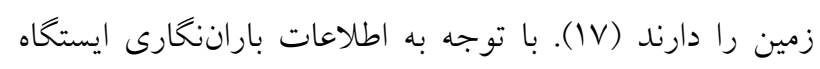

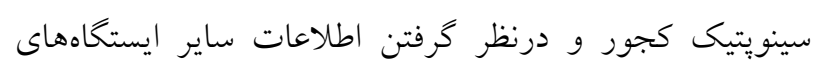

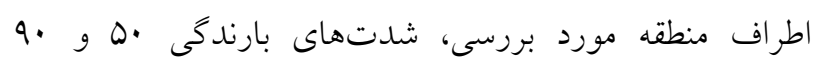

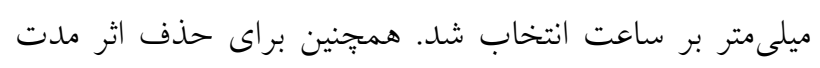

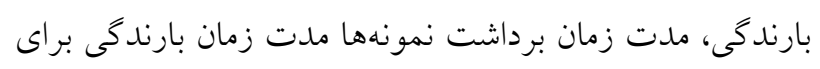

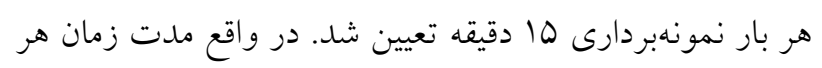

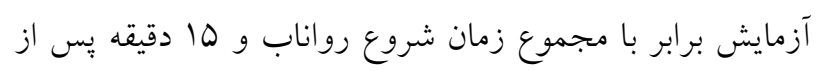
آن مدنظر قرار كرفت.

\section{- خصوصيات و مقادير ورمى كمبوست و نانو كود}

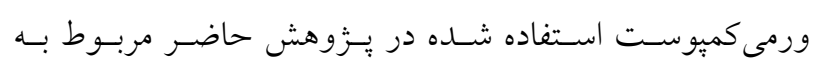

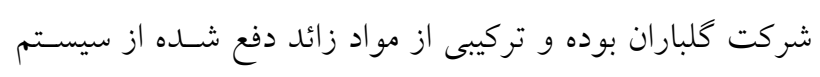

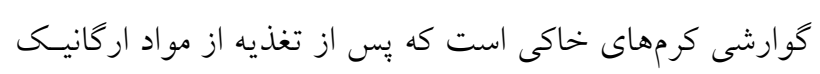

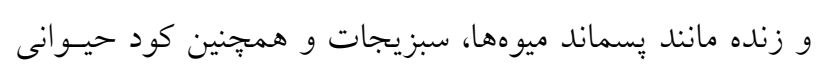

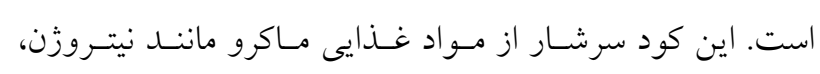

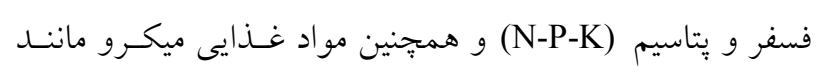

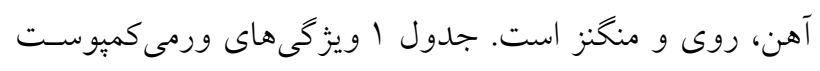

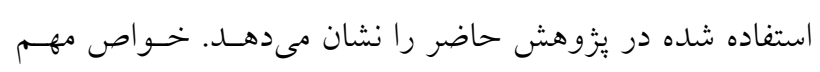

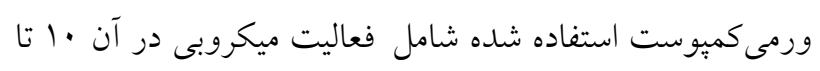

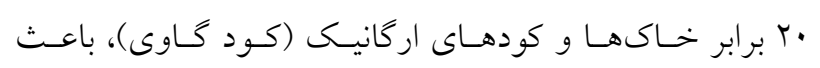

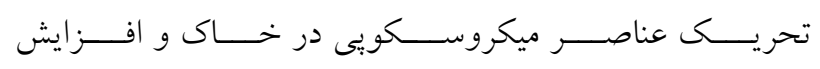

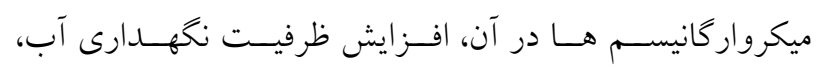

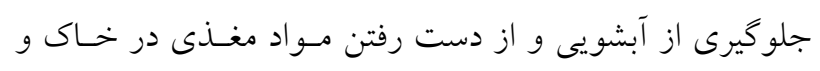

منطقه جمع آورى خاك شيب IV درصد انتخاب شــ. خـاك

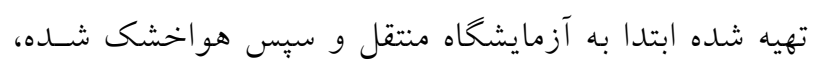

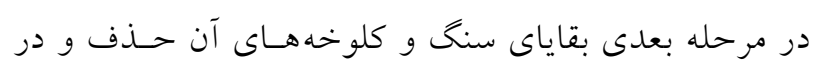

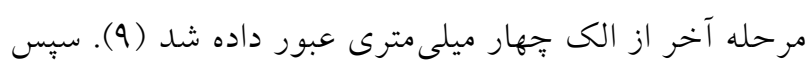

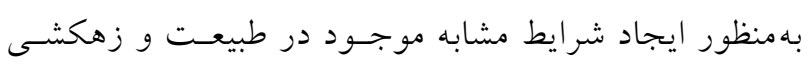

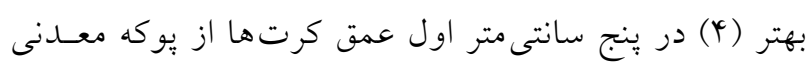

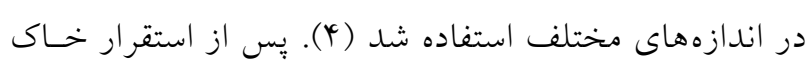

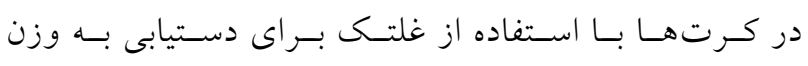
مخصوص ظاهرى خاك منطقه (19) مـورد مطالعسه رسـانده

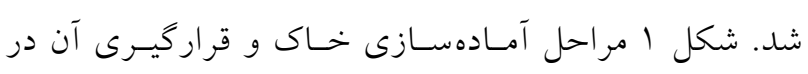

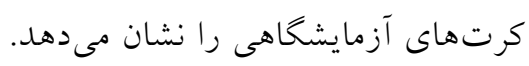
- انتخاب سطحهاى رطوبتى خاك

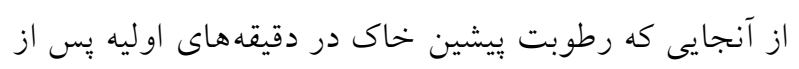

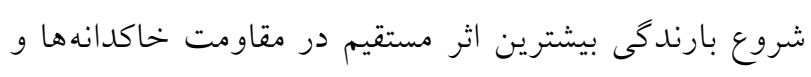

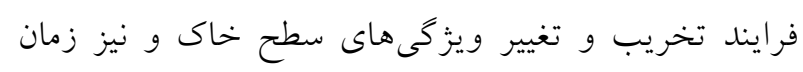

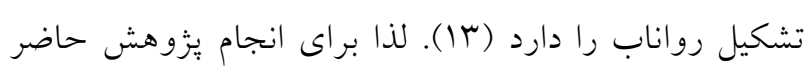

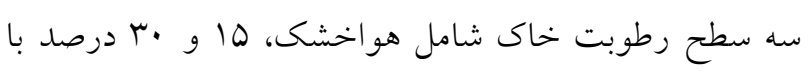

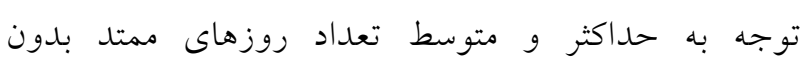

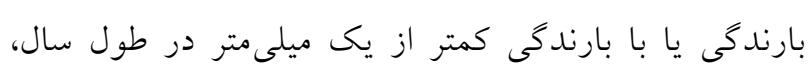

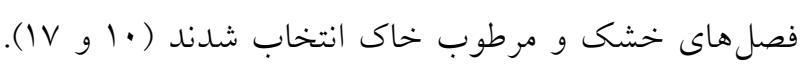

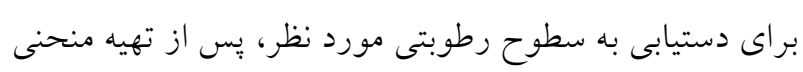

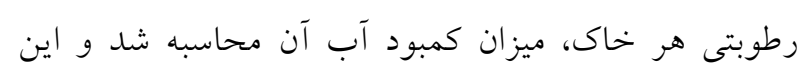

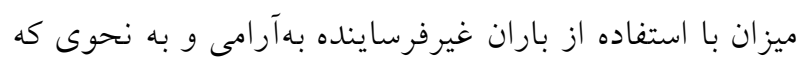

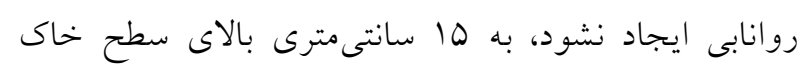

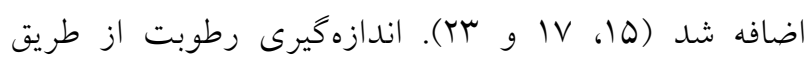

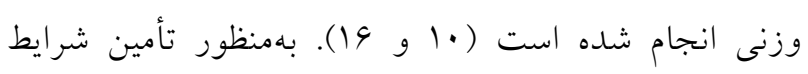

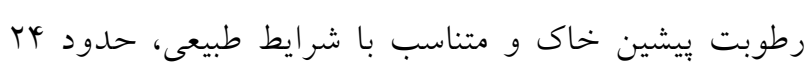
ساعت كرتهاى آماده شده تحت شرايط اشباع از كف فر فرار

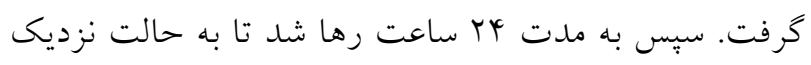

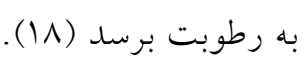



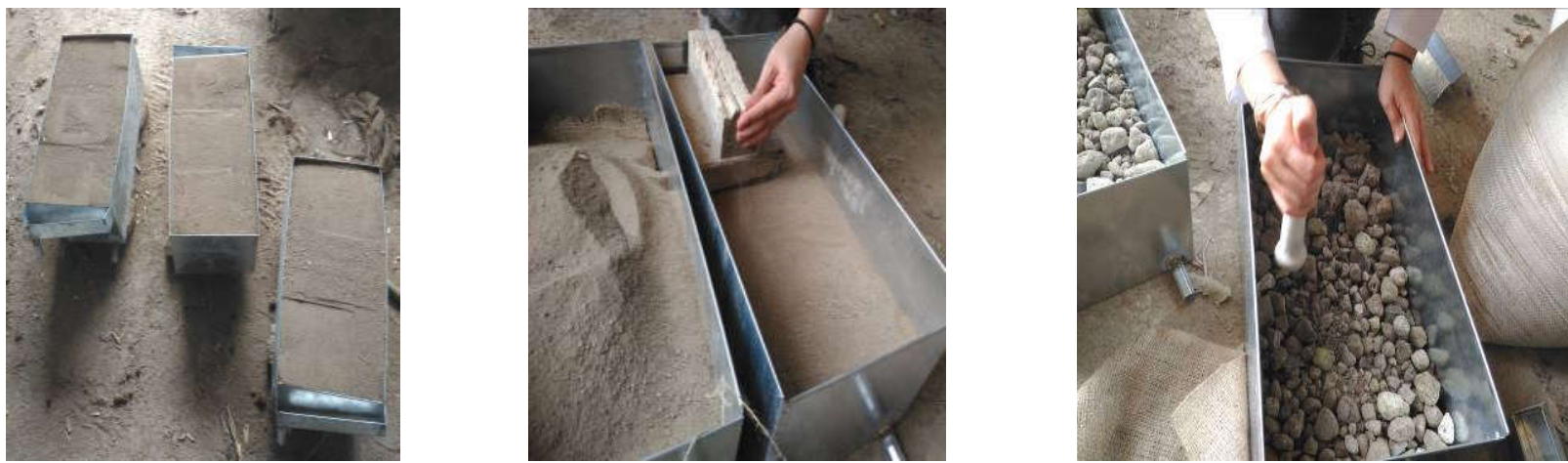

شكل ا. مراحل آمادهسازى كرتهاى آزمايشگاهى بهترتيب از راست به جب قرارگيرى بوكه در كف كرتها، قرار دادن خاك و كوبيدن

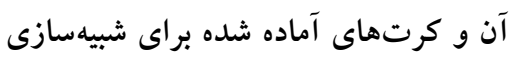

جدول ا. مشخصات ورمى كمِوست استفاده شده در بزّوهش حاضر

\begin{tabular}{|c|c|c|c|c|c|c|c|c|c|}
\hline $\mathrm{C} / \mathrm{N}$ & $\mathrm{EC}(\mathrm{dS} / \mathrm{m})$ & $\mathrm{pH}$ & OM (\%) & OC (\%) & $\mathrm{K}_{2} \mathrm{O}(\%)$ & K (\%) & $\mathrm{P}_{2} \mathrm{O}_{5}(\%)$ & $\mathrm{P}(\%)$ & $\mathrm{N}(\%)$ \\
\hline $1 T / \Gamma$. & $1 / T Y$ & $V / T^{4}$ & $r 1 / 10$ & $1 T / \cdot 9$ & $\cdot / T \Delta$ & $\cdot / Y 1$ & $\cdot / T \Lambda$ & $\cdot / T$ & $\cdot / 91$ \\
\hline
\end{tabular}

يكنواخت در سطح كرتها بخش شد. موسوىفر و همكاران

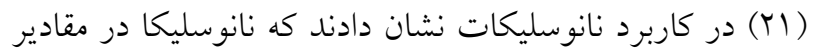

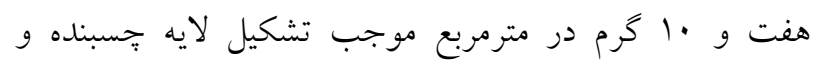

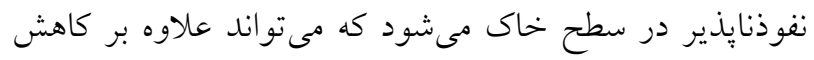

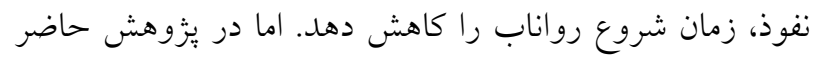

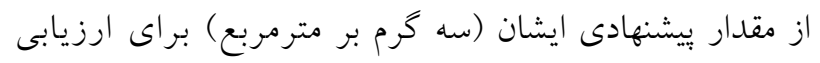

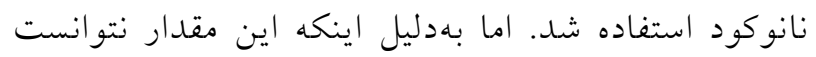
نتايج رضايتبخشى در تغييرات مؤلفهها داشته باشد.

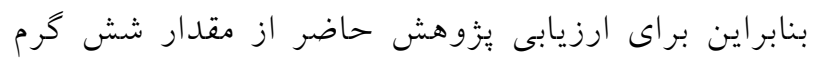

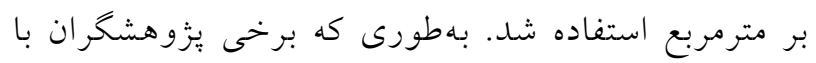

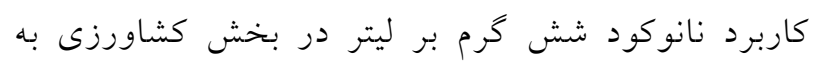

نتايج رضايتبخشى در اين زمينه دست يافتند (r).

- اندازهيرى هدررفت خاك و غلظت رسوب

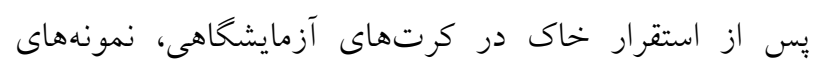

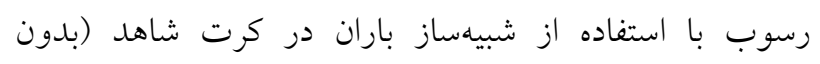
يوشش حفاظتى) براى رطوبتهاى ييشين خاك هوا خشك، 10

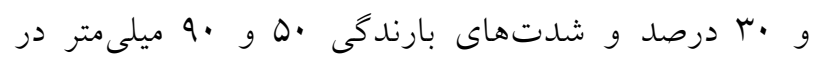

كاهش مصرف بـىرويه كودهاى شـيميايى (كـه باعـث آلـودكى محيط زيست و آبهاى زيرزمينى مىشود) است.

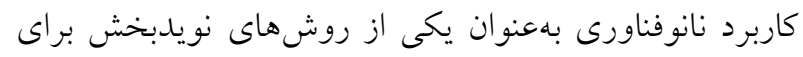
افزايش قابل توجه توليد غذاى مورد نياز جمعيت بهسرعت در

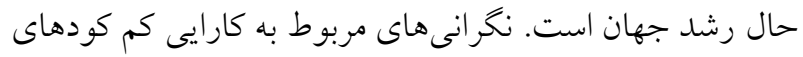

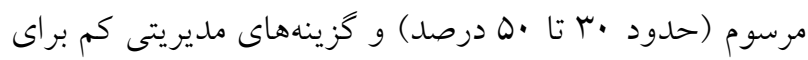

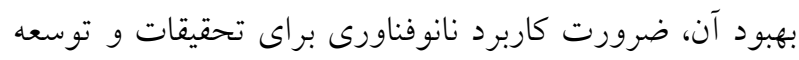

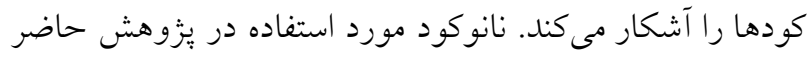

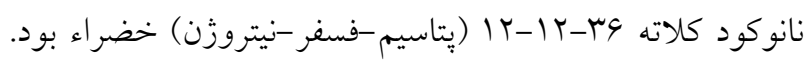

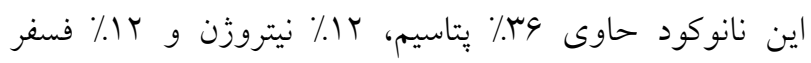
خالص در فرم كلاته و قابل جذب (برخلاف كودهاى شيميايى بائ

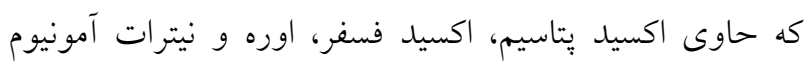

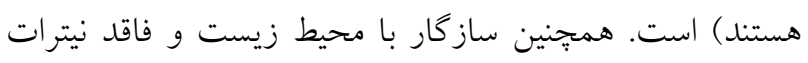

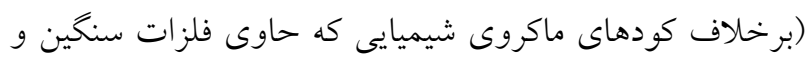

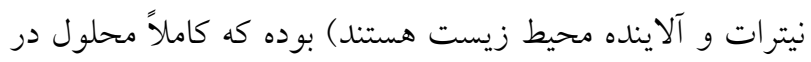

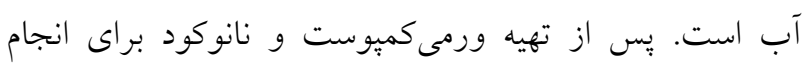

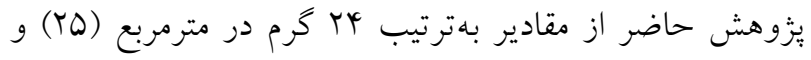

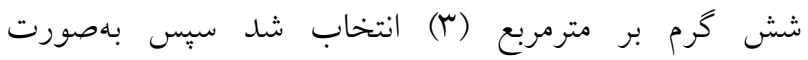




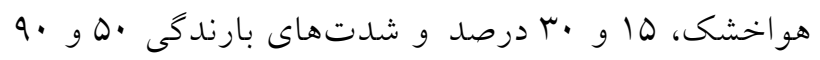

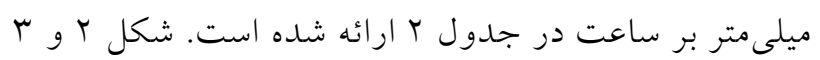

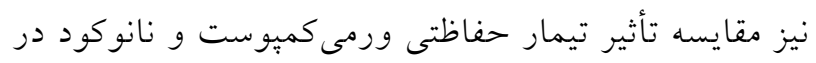

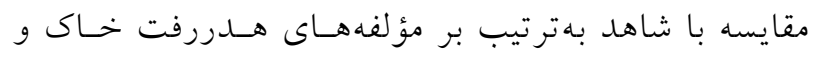

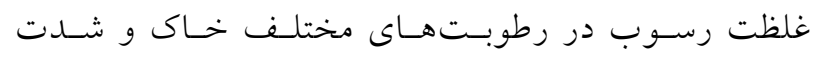

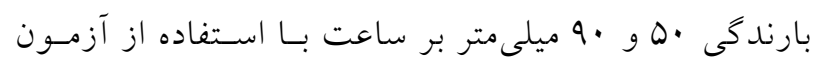

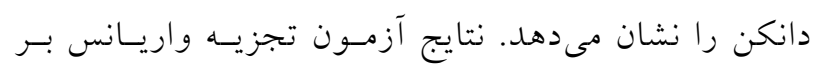

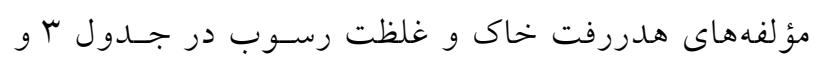

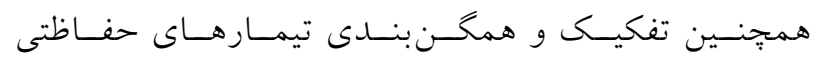
ورمى كميوست و نانوكود و سطوح رطوبت خاك با استفاده

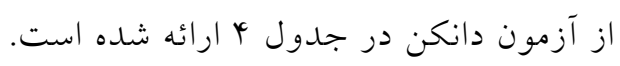
نتايج جدول r حاكى از آن است كه در شدت له آه ميلى متـر

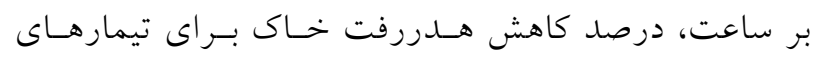

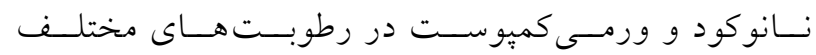

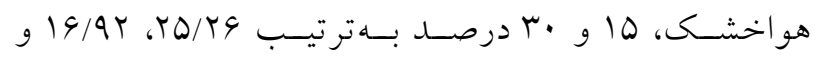

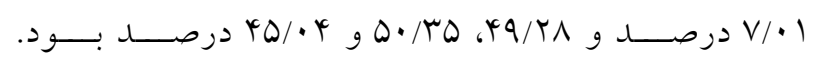
همجنين نتايج درصد تغييرات هدررفت خاك بـراى تيمـار

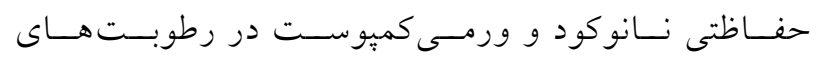

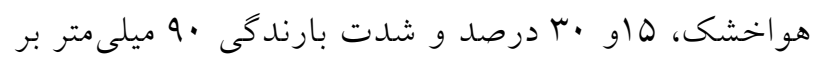

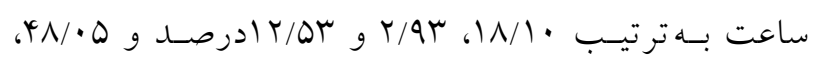

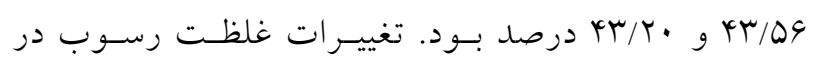

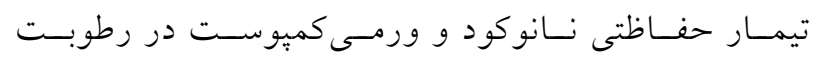

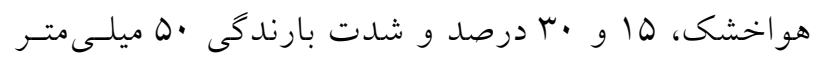

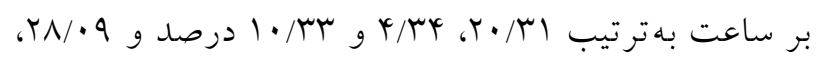

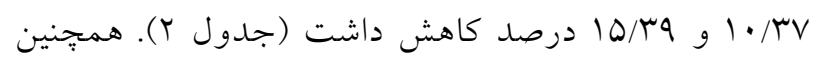

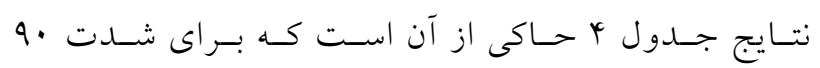

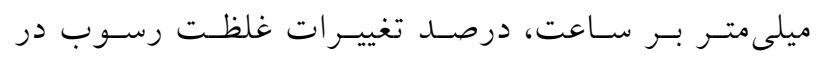

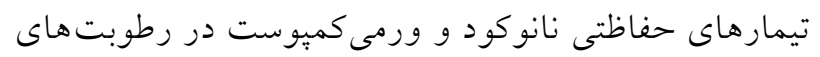

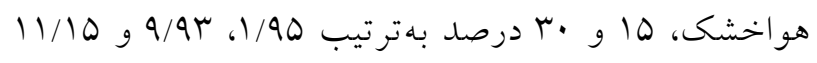
و هو R/M شاهد روند كاهشى داشت.
ساعت و در سه تكرار با فواصل زمانى سه دقيقهاى بهمدت

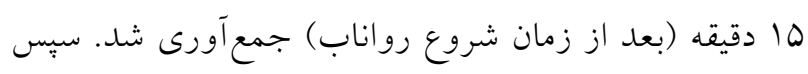

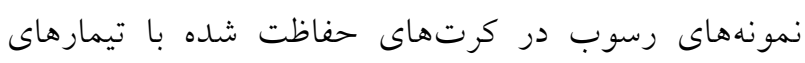

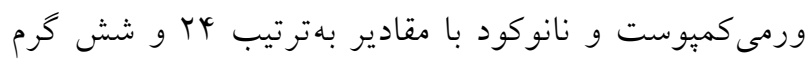

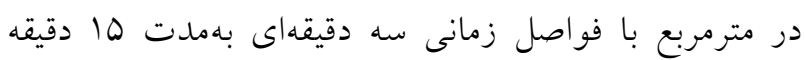

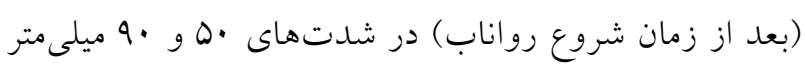

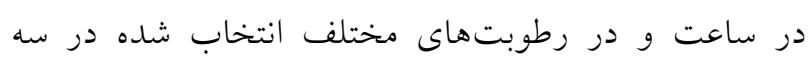

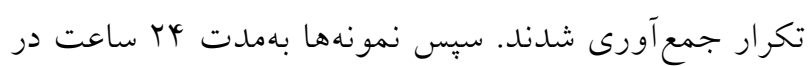

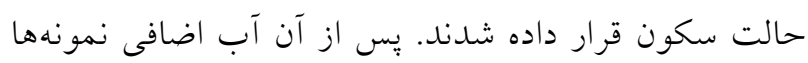

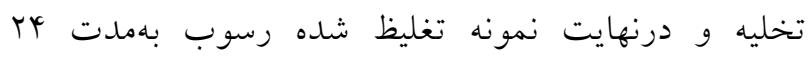

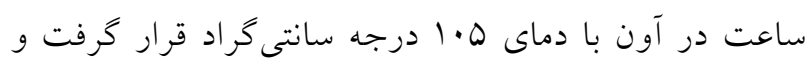

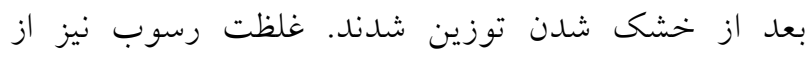

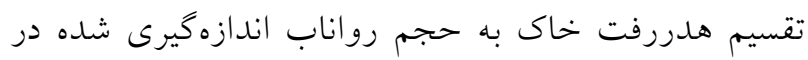
خروجى كرتها محاسبه شد (•).

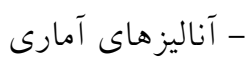

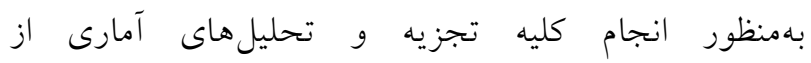
نرمافزارهاى Excel و SPSS26 استفاده شد. ابتدا با استفاده

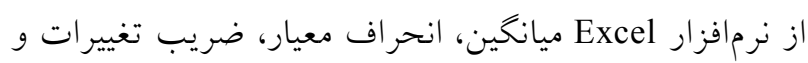

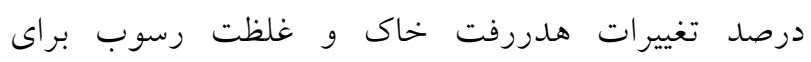

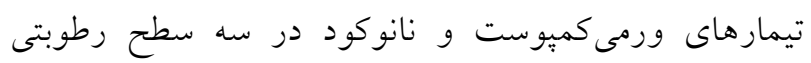

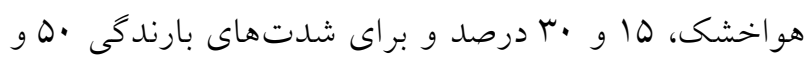

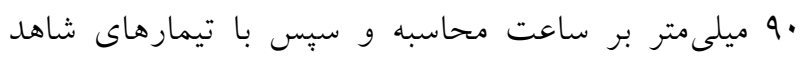

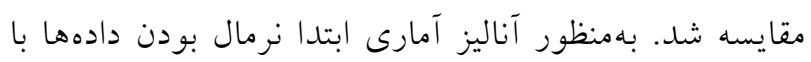

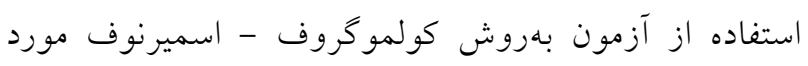

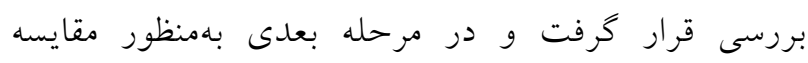

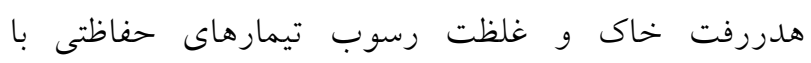

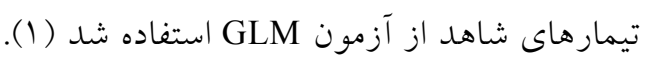

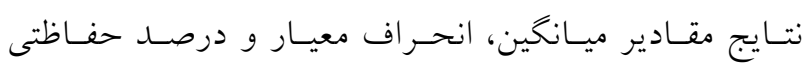
هدررفت خاك و غلظت رسوب در قبل و بعـــ از اسـتفاده از

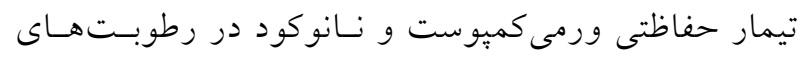


جدول r. نتايج هدررفت خاك و غلظت رسوب تيمارهاى حفاظتى ورمى كمبوست و نانو كود در رطوبتهاى به كار برده شده و شدت بارندگى •0 و • •9 ميلى متر بر ساعت

\begin{tabular}{|c|c|c|c|c|c|c|c|}
\hline \multicolumn{3}{|c|}{ غلظت رسوب (كرم بر ليتر) } & \multicolumn{3}{|c|}{ هدررفت خاى (كرم) } & \multirow[t]{2}{*}{ متغيرها } & \multirow[t]{2}{*}{ سطح رطوبتى (درصد) } \\
\hline ورمى كميوست & نانو كود & شاهد & ورمى كميوست & نانوكود & شاهد & & \\
\hline \multicolumn{8}{|c|}{ شدت •ه ميلى متر بر ساعت } \\
\hline $19 / \mathrm{NH}^{\mathrm{C}}$ & $1 N / \Delta D$ & $r \mu / r \Lambda$ & $\Lambda / \Delta \Delta$ & $1 Y / 9$. & $19 / 19$ & ميانخين & \multirow{3}{*}{ هو اخشك } \\
\hline .101 & $r / \wedge q$ & $4 / 91$ & $1 / \cdot r$ & $1 / 49$ & $1 / 01$ & انحراف معيار & \\
\hline$r N / q$ & $r \cdot / \mu l$ & - & $\nvdash q / r \wedge$ & $T Q / T G$ & - & درصد حفاظتى & \\
\hline $1 r / 9 V$ & $\mid Y / M$ & $10 / 90$ & $\Lambda / r$ & $1 r / 19$ & $19 / \mathrm{VT}$ & ميانخين & \multirow{3}{*}{10} \\
\hline$\cdot|\Lambda|$ & 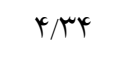 & $\cdot 10$ & $\cdot 109$ & $r / l \cdot$ & $r / 91$ & انحراف معيار & \\
\hline $1 \cdot \pi V$ & $r / 9 r$ & - & $\Delta \cdot / r \Delta$ & $19 / 9 r$ & - & درصد حفاظتى & \\
\hline $11 / 49$ & $1 Y / 19$ & $\mid r / \Delta \Lambda$ & $1 \cdot / 49$ & IV/VD & $19 / \cdot 9$ & ميانخين & \\
\hline$\cdot \mu \cdot$ & $1 / \cdot 1$ & $1 / 79$ & $\cdot / 9 V$ & $T / Q T^{r}$ & $r / 19$ & انحراف معيار & r. \\
\hline \multirow[t]{2}{*}{$10 / 49$} & 1./r & - & $\varphi \Delta / \cdot Y$ & $V / \cdot 1$ & - & درصد حفاظتى & \\
\hline & \multicolumn{7}{|c|}{ شدت ·9 ميلىمتر بر ساعت } \\
\hline $19 / .1$ & $\mathrm{IV} / \cdot \mathrm{Y}^{\mathrm{c}}$ & $\mid V / r \Lambda$ & $\mid r / r v$ & $r Y / \wedge$ & $r \Delta / V Y$ & ميانخين & \\
\hline $1 / \Delta 0$ & $1 / 9 V$ & $1 / \mathrm{V}$ & $T / M V$ & $r / 91$ & G/T & انحر اف معيار & هو اخشك \\
\hline $\mathrm{V} / \mathrm{M}$ & $1 / 90$ & - & $\hat{\forall} N / 0$ & $1 N / 1$ & - & درصد حفاظتى & \\
\hline $9 / 9$. & $14 / \pi r$ & $10 / 1$ & $19 / 49$ & Tr/QG & $r q / \cdot r$ & ميانخين & \\
\hline 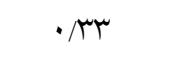 & $1 / 1$ & $1 / \cdot 9$ & T/KT & r & $\mu / \Lambda$. & انحر اف معيار & 10 \\
\hline$r V / r y$ & $9 / 94$ & - & $k r / 09$ & $r \cdot / 9 r$ & - & درصد حفاظتى & \\
\hline $1 / q$ & $9 / \cdot 1$ & $1 \cdot / T r$ & IV/VG & TV/TO & $M / T V$ & ميانخين & \\
\hline$\cdot / \cdot V$ & $1 / \wedge 1$ & $r / \mu$ & T/TH & $r / l r$ & $r / N r$ & انحر اف معيار & r. \\
\hline$|r / 9|$ & $11 / 10$ & - & $\kappa \mu / r$. & Ir/or & - & درصد حفاظتى & \\
\hline
\end{tabular}




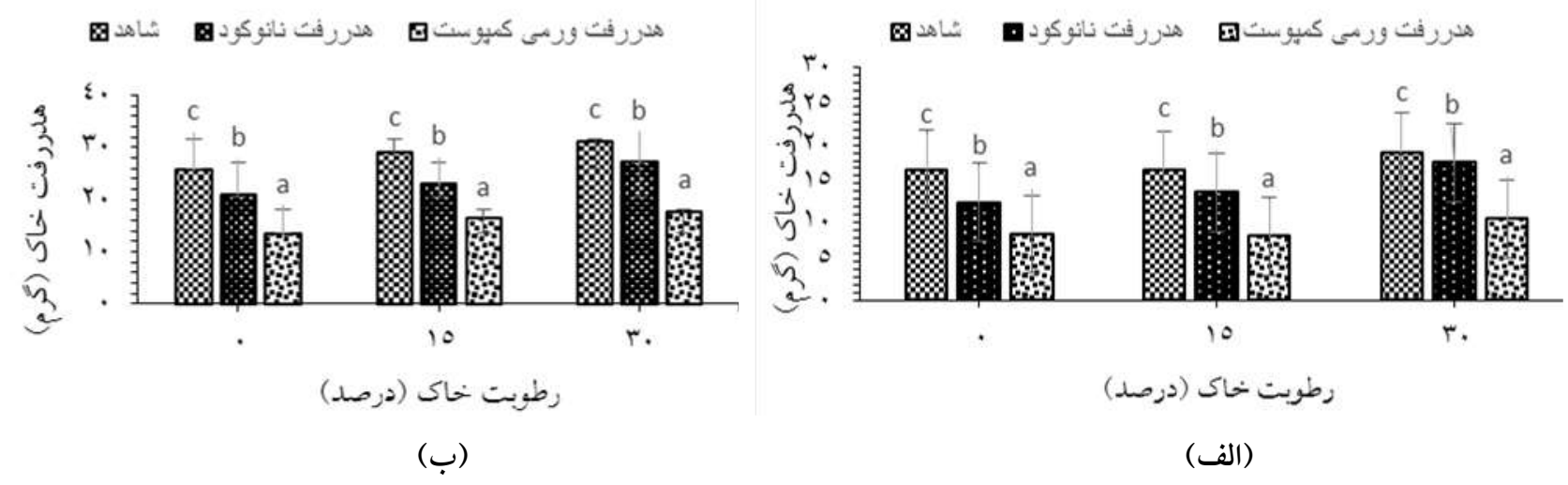

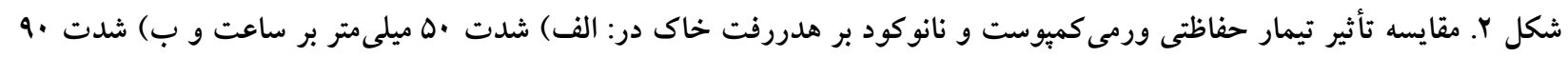
ميلى متر بر ساعت

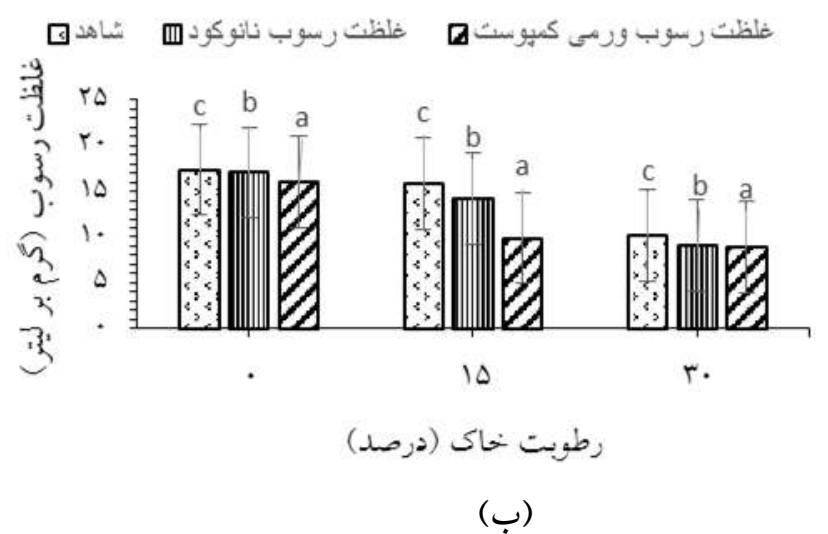

شكل r. مقايسه تأثير تيمار حفاظتى ورمى كميوست و نانو كود بر غلظت رسوب در: الف) شدت •ه ميلىمتر بر ساعت و ب) شدت هيل ميلى متر بر ساعت

بزوهشكران نشان دادند ذرات نانو با جذب آب (درصورتى كه به

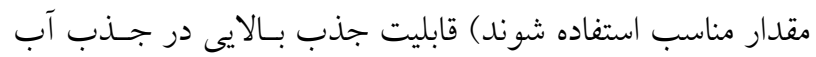

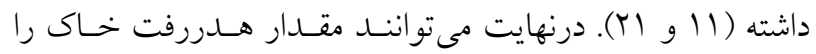

كاهش دهند. نتايج تيمار ورمى كمبوست با نتايج هاتى و همكـاران

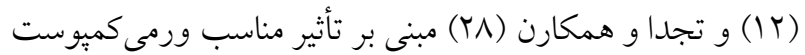

بر كاهش هدررفت و حفظ ساختمان خاك مطابقت دارد. شـكل ب نيز مقايسه تيمار حفاظتى ورمى كمبوست، نانوكود و تيمـار شـاهد

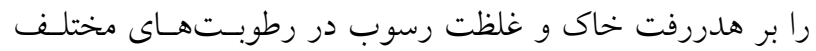

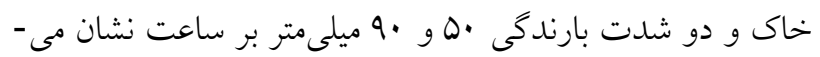

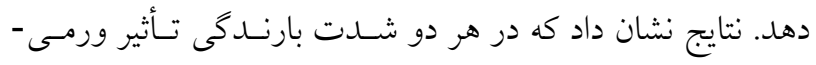

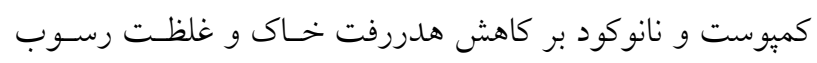

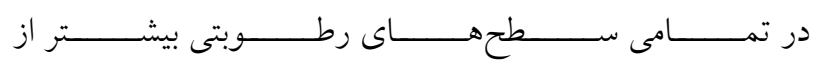

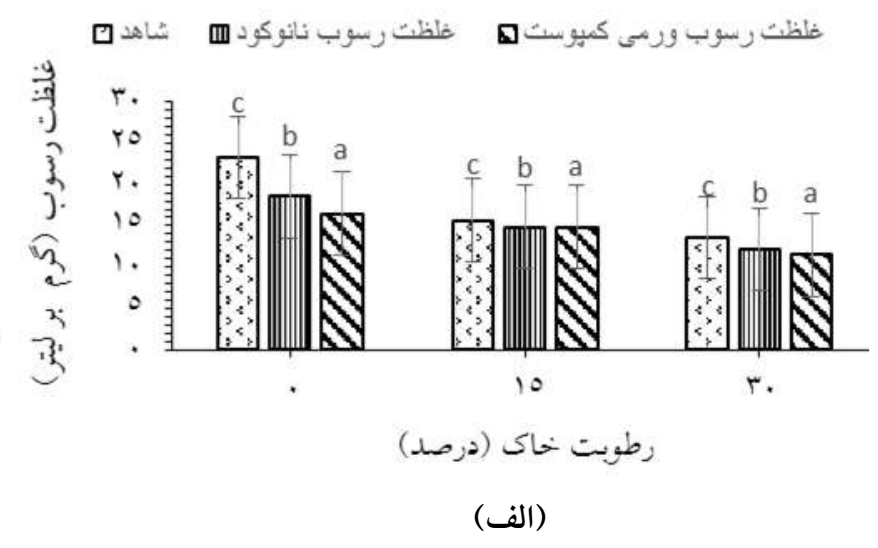

همانكونه كه نتايج نشان مىدهـــ درصــ حفـاظتى تيمـارهـاى

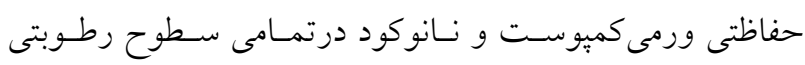

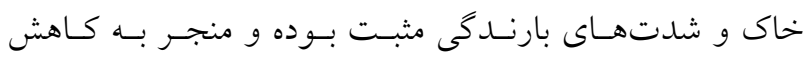
هدررفت خاك نسبت به تيمار شاهد شده است اما مقايسه نتايج

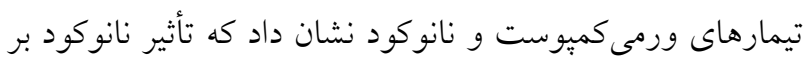

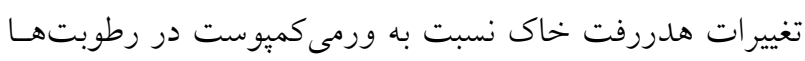

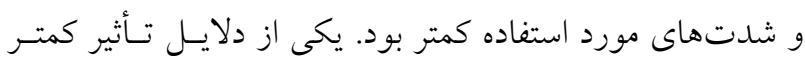
نـانودكود بــر تغييـرات هـــررفت خــاك نسـبت بــه تيمـار ورمى كميوست مىتواند اين باشد كه اين افزودنى بهدليل ايجـاد

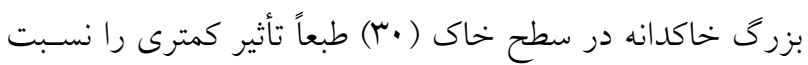

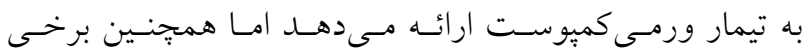


جدول r. نتايج آزمون تجزيه واريانس تيمارهاى حفاظتى، رطوبتهاى خاك و شدت بارندگى بر هدررفت خاك و غلظت رسوب

\begin{tabular}{|c|c|c|c|c|c|c|}
\hline سطح معنى دارى & 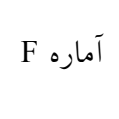 & ميانخين مربعات & درجه آزادى & مجموع مربعات نوع & متغير & \\
\hline$\cdot / \cdots$ & $V T^{E} / Y^{c}$ & $019 / 49$ & r & $1 \cdot M T / D T$ & هدررفت خاى & \multirow{2}{*}{ تيمارهاى حفاظتى } \\
\hline$\cdot / \cdots$ & $9 / 90$ & 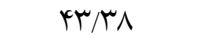 & r & YVG/DN & غلظت رسوب & \\
\hline$\cdot / \cdots$ & $11 / 29$ & $11 / 01$ & r & $11 / 01$ & هدررفت خاك & \multirow{2}{*}{ رطوبت خاك } \\
\hline$\cdot / \cdots$ & $\Delta r / \cdot \Delta$ & TrN/Tq & r & TrN/Tq & غلظت رسوب & \\
\hline$\cdot / \cdots$ & $10 / / r 9$ & $1 \cdot 90 / \cdot r$ & 1 & $1 \cdot 90 / \cdot r$ & هدررفت خاك & \multirow{2}{*}{ شدت بارند } \\
\hline$\cdot / \cdots$ & $V 1 / 01$ & $V \wedge / 90$ & 1 & $V \wedge / 90$ & غلظت رسوب & \\
\hline$\cdot / \cdots$ & N/9T & rqV/AY & r & $\Delta r \Delta / 9 q$ & هدررفت خاك & \multirow{2}{*}{ شدت بارندگى × رطوبت خاى ـ } \\
\hline$\cdot / \cdots$ & $1 Y / \cdot 9$ & $q \mu / r V$ & r & $1 \wedge \& / \Delta 0$ & غلظت رسوب & \\
\hline$\cdot / \cdots$ & $4 q / 4$. & IOHYTL & r & $r .9 \wedge / \mathrm{VI}$ & هدررفت خاك & \multirow{2}{*}{ تيمار حفاظتى × شدت بارندگى - } \\
\hline$\cdot / \cdots$ & $Y \Lambda / F V$ & $T T \cdot / I T$ & r & $r 4 \cdot / r q$ & غلظت رسوب & \\
\hline$\bullet$ & $99 / 99$ & $r \mid G r / D r$ & r & $\wedge \varphi \Delta Y / \lambda$ & هدررفت خاك & \multirow{2}{*}{ تيمار حفاظتى × رطوبت خاى } \\
\hline$\cdot \cdots$ & $9 / 91$ & $01 / 9 \mathrm{~V}$ & 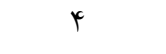 & $T \cdot 9 / \mathrm{V}$ & غلظت رسوب & \\
\hline
\end{tabular}

جدول وا. تفكيك و همخنبندى تيمارهاى حفاظتى ورمى كميوست و نانوكود و سطوح رطوبت خاك با استفاده از آزمون دانكن

\begin{tabular}{|c|c|c|c|c|}
\hline زيرگروه r & زيركروه r & زيرگروه & 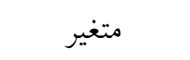 & \\
\hline شاهد (r/Tr/Y) & نانوكود (19/TV) & ورمى كميوست (r/D/ I I) & هدررفت خاك & \multirow{2}{*}{ تيمار حفاظتى } \\
\hline شاهد ( 1ه/9T) & نانو كود ( & ورمى كميوست (س/NY I I ) & غلظت رسوب & \\
\hline$(\Lambda \vee / \uparrow \wedge) \uparrow \cdot$ & هواخشك (DY/99) & $(K Y / Y \vee V) 10$ & هدررفت خاك & \multirow{2}{*}{ رطوبت خاى } \\
\hline--- & 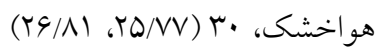 & $(1 \% / 94) 10$ & غلظت رسوب & \\
\hline
\end{tabular}

كزارش شده است كه نانوذرات بهسبب برخــوردارى از نسـبت سطح به حجم و قابليت جذب زيـاد، امكـان اتصـال حسداكثرى ذرات خاك با حداقل مقدار افزودنى را فراهم مى كنند. جدول

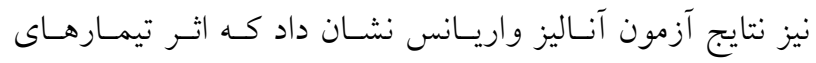
حفاظتى ورمى كميوست و نانوكود بر هدررفت خـاك و غلظـت رسوب در سطح اعتماد 99 درصد معنسى دار بـود در ايسن راسـتا آرتور و همكاران (Y) تأثير مثبت و معنى دار كميوست بـر ثبـات

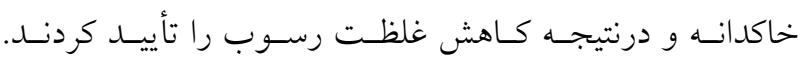
همجينين نتايج يزوهش حاضر با نتـايج موسـوىفـر و همكـاران
تيمار شاهد بود. دليل اين امر را مىتوان به سطح بالاى مواد آلى موجود در ورمى كميوست نسبت داد كه منجربه بهبـود سـاختمان خاك، جلو گيرى از تخريب خاكدانهها و بزرگتر شدن خلـل و فرج موجود در خاى و طبعاً هدايت آب به لايسههـاى بـايين تـر خـاك و افـزايش ظرفيـت نخهـــارى آب در خــاك شـــه اسـت. همجنين نانوكود نيز با ايجاد جسبندگى در سطح خاك از حمل ذرات توسط رواناب جلو گيرى كرده و بنابراين نسبت به شـاهد مقدار غلظت رسوب كمترى خواهــ داشـت. بـهــور كلى بــر

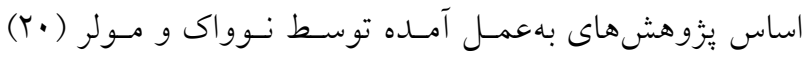




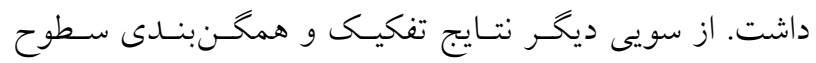

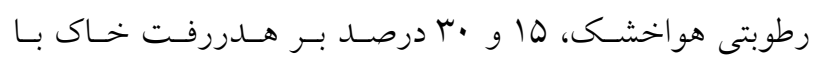

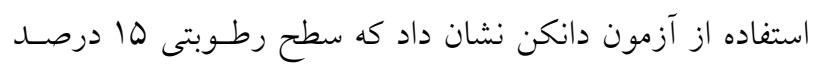

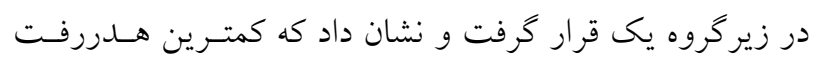

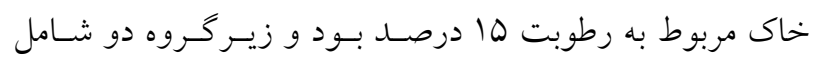

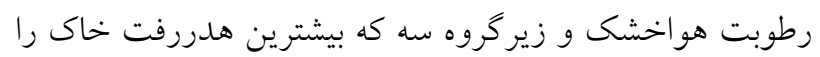

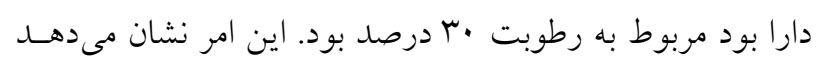

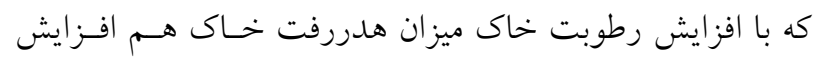

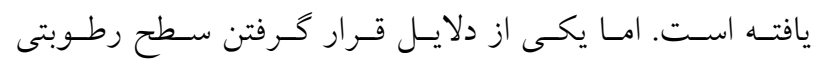

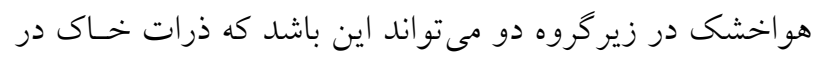

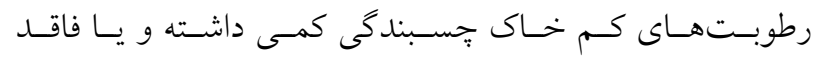

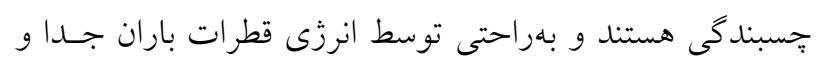
سبس توسط رواناب حمل مىشوند كه درنهايت مى تواند ميـزان

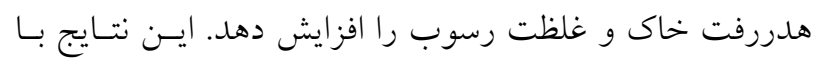

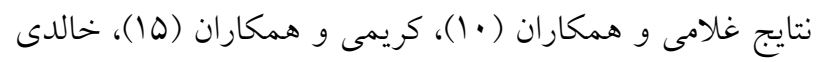

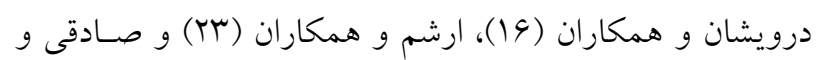

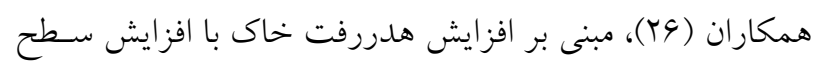

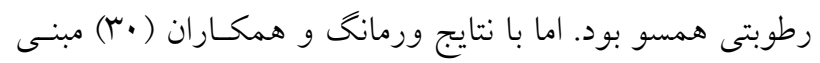

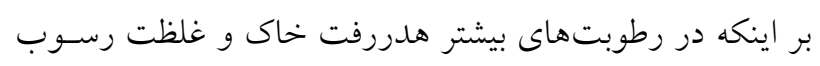

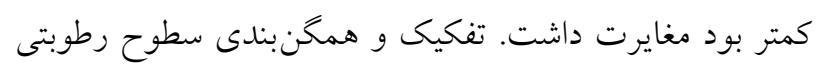

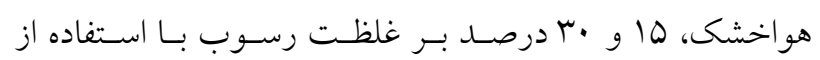

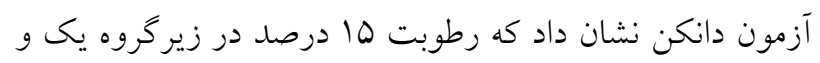

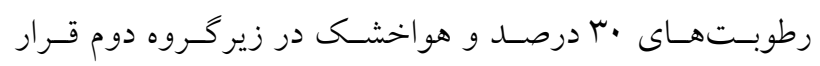

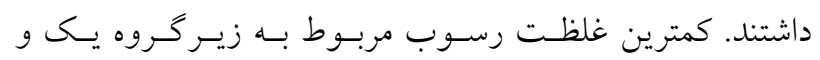

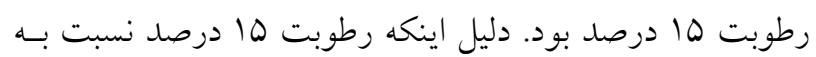

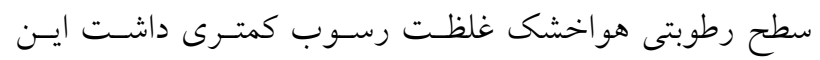

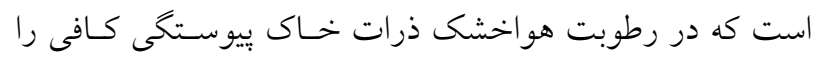

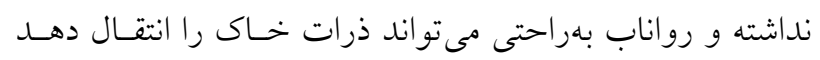

\section{نتيجه كيرى}

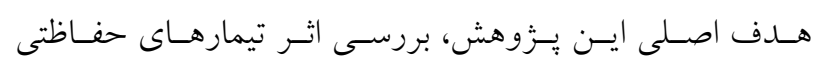

مبنى بر تأثير مثبت ورمىكميوست بر تعييـرات هـدررفت (YI)

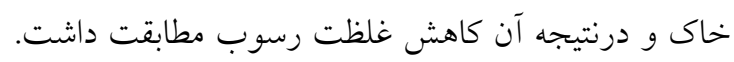
رطوبت خاك و شدت بارندكى يارامترهاى مهمسى در تغييـرات

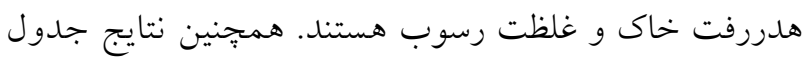

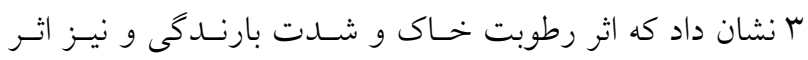

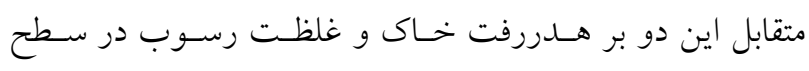

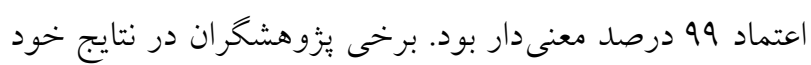
اثر معنى دار رطوبت خاك بر مؤلفههاى مورد نظر را تأكيد كرده-

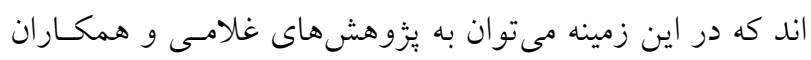

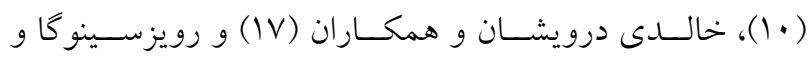

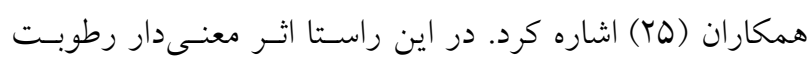
ييشين خاك بر غلظت رسوب با نتايج رويزسينو كا و همكـاران

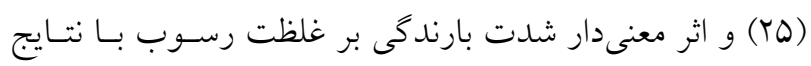

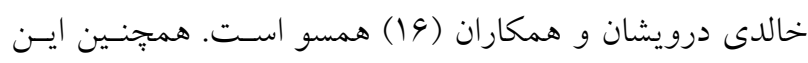

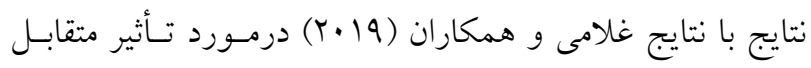
تيمار حفاظتى بايوجهـار و رطوبـت خـاك، كريمسى و همكـاران

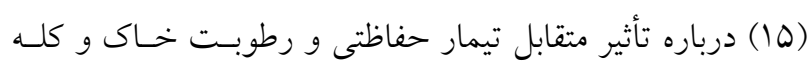

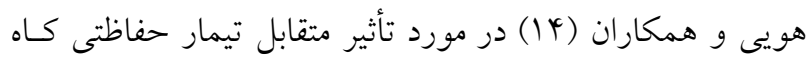

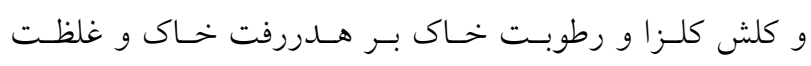

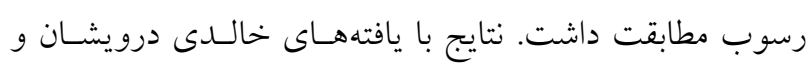

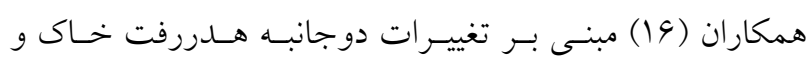
غلظت رسوب در شدتهاى باران و رطوبتهاى ييشـين خـاك

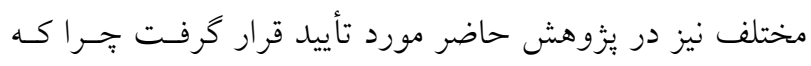
با افزايش سطح رطوبتى خـاك درصـد، هـــررفت خـاك و نيـز غلظت رسوب افزايش يافت.

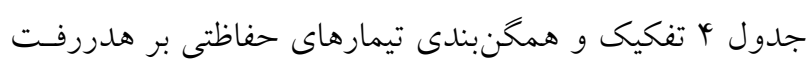

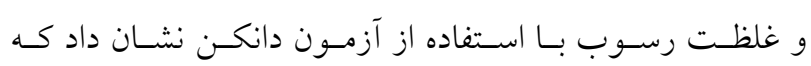

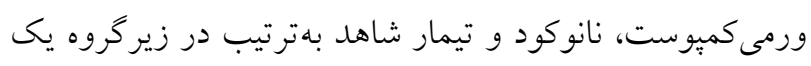
تا سه قرار داشتند. اين موضوع نشاندهنده اين است كـهـ تيمـار

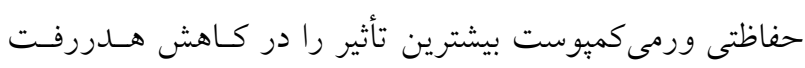

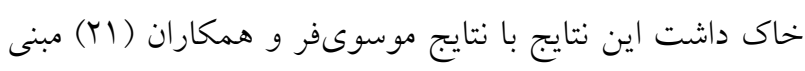

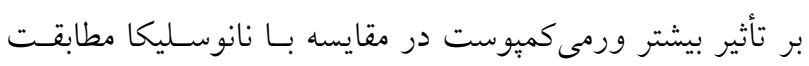




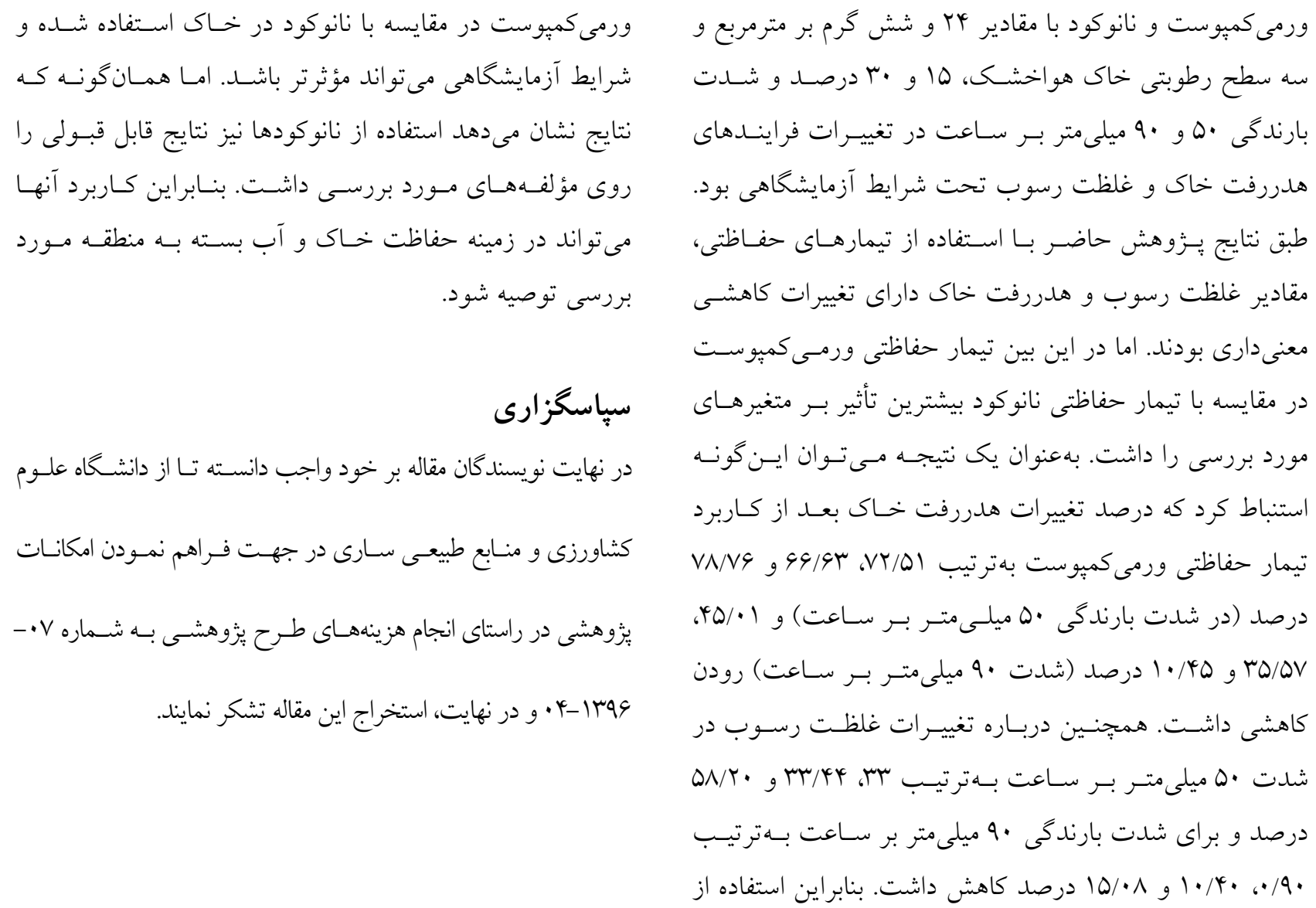

\section{منابع مورد استفاده}

1. Arnaez J., T. Lasanta, P. Ruiz-Flano and L. Ortigosa. 2007. Factors affecting runoff and erosion under simulated rainfall in Mediterranean Vineyards. Soil and Tillage Research 93: 324-334.

2. Arthur, E., W. M. Cornelisa, J. Vermang and E. De Rocker. 2011. Effect of compost on erodibility of loamy sand under simulated rainfall, Catena 85: 67-72.

3. Bayati, F., A. Aynehband and E. Fateh. 2014. Effect of different rates and application times of nano-iron on yield and yield components of canola (Brassica napus L.). Iranian Journal of Fiels Crop Research 12(4): 805-812. (In Farsi).

4. Defersha, M. B., S. Quraishi and A. Melesse. 2011. The effect of slope steepness and antecedent moisture content on interrill erosion, runoff and sediment size distribution in the highlands of Ethiopia. Hydrology Earth System Science 15: 2367-2375.

5. Demir, Z. 2019. Effects of vermicompost on soil physicochemical properties and lettuce (Lactuca sativa Var. Crispa) yield in greenhouse under different soil water regimes. Communications in Soil Science and Plant Analysis 50(17): 2151-2168.

6. Doan, T. T., T. Henry-des-Tureaux, C. Rumpel, J. L. Janeau and P. Jouquet. 2015. Impact of compost, vermicompost and biochar on soil fertility, maize yield and soil erosion in Northern Vietnam: a three-year mesocosm experiment. Science of the Total Environment 514: 147-154.

7. Fletcher, D. 2007. Soil Erosion Control on Banks Peninsula: A Bioengineering Approach.

8. Gessesse B., W. Bewket and A. Bräuning. 2015. Model-based characterization and monitoring of runoff and soil erosion in response to land use/land cover changes in the Modjo watershed, Ethiopia. Land Degradation and Development 26(7): 711-724.

9. Gholami, L., L. Banasik, S. H. R. Sadeghi and A. Khaledi Darvishan. 2014. Effectiveness of straw mulch on infiltration, splash erosion, runoff and sediment in laboratory conditions. Journal of Water and Land Development 22 (VII-IX): 51-60. 
10. Gholami, L., N. Karimi and A. Kavian. 2019. Soil and water conservation using biochar and various soil moisture in laboratory conditions. Catena 182: 104-151.

11. Hasanzadeh, N., L. Gholami, A. Khlaedi Darvishan and H. Uonesi. 2018. Nanoclay effect on changing runoff and sediment at small plots. The 13th National Conference on Watershed Management Science \& Engineering of Iran and the 3rd National Conference on Conservation of Natural Resources and Environment.

12. Hati, K. M., A. Swarup, A. K. Dwivedi, A. K. Misra and K. K. Bandyopadhyay. 2007. Changes in physical properties and organic carbon status at the topsoil horizon of a Vertisol of central india after 28 years of continuous cropping, fertilization and manuring. Agriculture Ecosystems Environment 119(1): 127-134.

13. Hawke, R. M., A. G. Price and R. B. Bryan. 2006. The effect of initial soil water content and rainfall intensity on near-surface soil hydrologic conductivity: A laboratory investigation. Catena 65: 237-246.

14. Kalehhouei, M., A. Kavian, L. Gholami and Z. Jafarian. 2017. Protective impact of colza straw (Brassica napus L.) on runoff and soil loss control using rainfall simulation. Watershed Management Research 31(118): 72.82. (In Farsi).

15. Karimi, N., L. Gholami and A. Kavian. 2019. Protective role of biochar in different soil moisture for prevent soil loss in laboratory conditions. Journal of Water and Soil Scienc 23(3): 223-235. (In Farsi).

16. Khaledi Darvishan, A., K. Banasik, S. H. R. Sadeghi, L. Gholami and L. Hejduk. 2015. Effects of rain intensity and initial soil moisture on hydrological responses in laboratory conditions. International Agrophysics 29: 165-173.

17. Khaledi Darvishan, A., S. H. R. Sadeghi, M. Homaee and M. Arabkhedri. 2014. Measuring sheet erosion using synthetic color-contrast aggregates. Hydrological Processes 28(15): 4463-4471.

18. Kheirfam, H., S. H. R. Sadeghi, M. Homaee and B. Zarei Darki. 2014. Role of soil microorganisms in soil and water loss control. Extension and Development of Watershed Management 2(5): 19-27.

19. Kukal, S. S. and M. Sarkar. 2010. Splash erosion and infiltration in relation to mulching and polyvinylalcohol application in semi-arid tropics. Archive of Agronomy and Soil Science 56(6): 697-705.

20. Mueller, N. C. and B. Nowack. 2010. Nanoparticles for remediation: solving big problems with little particles. Elements 6(6): 395-400.

21. Mousavifar, S. S., S. H. R. Sadeghi and N. Bahramifar. 2017. Effects of individual and combined application of vermicompost and silica nano particles on soil infiltration. Journal of Water and Soil Resources Conservation 7(1): 49-59. (In Farsi).

22. Najafivafa, Z., N. Falahi, M. Zare, S. Bohloli and A. Sirousmehr. 2014. The effects of different levels of using Zinc nano chelated fertilizers and humic acid on growth parameters and on some quality and quantity characteristics of medicinal plants of savory. Academy for Environment and Life Sciences India 4(6): 56-67.

23. Orsham, A., A. M. Akhundali and A. Behnia. 2010. Effect of soil antecedent moisture contents on runoff and sedimentation values with simulated rainfall method. Iranian Journal of Range and Desert Research 16(4): 445455. (In Farsi).

24. Pandiyana, C., K. Balajib, S. Saravanana, G. Shylajaa and G. Ragavendra. 2020. Effect of vermicompost application on soil and growth of the plant Sesamum indicum L. Preprints. (doi: 10.20944/preprints202002.0080.v1).

25. Ruiz-Sinoga J. D., A. Romero Diaz, E. FerreBueno and J. F. Martinez Murillo. 2010. The role of soil surface conditions in regulating runoff and erosion processes on a metamorphic hillslope (Southern Spain), soil surface conditions, runoff and erosion in Southern Spain. Catena 80: 131-139.

26. Sadeghi, S. H. R., Z. Hashemi Ariyan and Z. Karimi. 2015. Runoff generation and soil loss control using combined application of vermicompost and Vinasse. Water Reuse 2(1): 81-91. (In Farsi).

27. Thu Doan, T., H. Tureaux, C. Rumpel, J. Janeau and P. Jouquet. 2015. Impact of compost, vermicompost and biochar on soil fertility, maize yield and soil erosion in Northern Vietnam: A three-year mesocosm experiment. Science of the Total Environment 514: 147-15.

28. Tejada, M. and J. L. Gonzalez. 2008. Influence of two organic amendments on the soil physical properties, soil losses, sediments and runoff water quality. Geoderma 145: 325-334.

29. Truman, C. C., T. L. Potter, R. C. Nuti, D. H. Franklin and D. D. Bosch. 2011. Antecedent water content effects on runoff and sediment yields from two Coastal Plain Ultisols. Agricultural Water Management 198: 1196-1189.

30. Vermang, J., V. Demeyer, W. M. Cornelis and D. Gabriels. 2009. Effect of antecedent soil-water content on aggregate stability and erodibility of a loess soil. Soil Society of America Journal 73: 718-726.

31.Zomorodian, S. M. A., and A. Soleymani. 2017. The Effect of nanosilica additive on soil erodibility. Journal of Water and Soil Science 21(1): 217-227. (In Farsi). 


\title{
Variability of Sediment Components with Application of Vermicompost and Nano-manure and Various Moisture Levels
}

\author{
L. Gholami ${ }^{*}$, A. Khaledi Darvishan ${ }^{2}$ and N. Karimi ${ }^{1}$
}

(Received: June 14-2020; Accepted: December 21-2020)

\begin{abstract}
Soil loss can cause many intra-regional and extra-regional problems, on the other hand, the effect of soil moisture on processes of soil loss and sediment yield for the identification and simulation of soil hydrological response is necessary. Therefore, the application of soil conditioners is essential for soil and water conservation. The present study was conducted to investigate the effect of soil conditioners of vermicompost and nano-manure on variables of soil loss and sediment concentration at moistures of airdried, 15 and $30 \%$, and rainfall intensities of 50 and $90 \mathrm{~mm} \mathrm{~h}^{-1}$. The obtained results in addition to confirmation of the significant effect of each conservation treatment at the level of 99 percent on the intended components showed that the conservation treatment of vermicompost compared to nano-manure treatment had more effect on measured variables. Also, the conservation treatment of vermicompost could decrease the soil loss at soil moisture air-dried, 15, and 30 percent with rates of 72.15, 66.63, and 78.76 percent $\left(50 \mathrm{~mm} \mathrm{~h}^{-1}\right)$, respectively, and $45.01,35.57$, and 10.45 percent (of $90 \mathrm{~mm} \mathrm{~h}^{-1}$ ), respectively. The effect of conservation treatments, soil moistures, and rainfall intensity and the interaction effects of conservation treatments $\times$ rainfall intensity and rainfall intensity $\times$ soil moisture on changes of soil loss and sediment concentration were significant at the level of 99 percent. The application of vermicompost and nano-manure had acceptable results on studied parameters but the vermicompost effect was more than nanomanure. Therefore, due to the widespread use of different types of conditioners, nowadays, it is needed to move the application feasibility of conditioners such as vermicompost and nano-manure that these have not the adverse effects of environmental.
\end{abstract}

口

Keywords: Soil amendments, Soil erosion, Soil antecedent moisture, Sediment concentration, Laboratory plot

1. Department of Watershed Management Engineering, Faculty of Natural Resources, Sari Agricultural Sciences and Natural Resources University, Sari, Iran.

2. Department of Watershed Management Engineering, Faculty of Natural Resources, Tarbiat Modares University, Noor, Iran.

*: Corresponding author, Email: 1.gholami@sanru.ac.ir 